NUREG-0725

Rev. 5

\title{
Public Information Circular for Shipments of Irradiated Reactor Fuel
}

U.S. Nuclear Regulatory

Commission

Office of Nuclear Material Safety and Safeguards

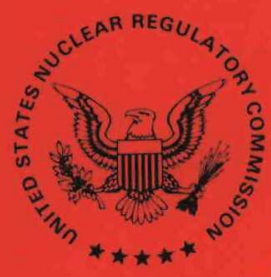

DO NOT MICROFLM

COVER 


\section{NOTICE \\ Availability of Reference Materials Cited in NRC Publications}

Most documents cited in NRC publications will be available from one of the following sources:

1. The NRC Public Document Room, 1717 H Street, N.W.

Washington, DC 20555

2. The Superintendent of Documents, U.S. Government Printing Office, Post Office Box 37082 , Washington, DC 20013-7082

3. The National Technical Information Service, Springfield, VA 22161

Although the listing that follows represents the majority of documents cited in NRC publications, it is not intended to be exhaustive.

Referenced documents available for inspection and copying for a fee from the NRC Public Document Room include NRC correspondence and internal NRC memoranda; NRC Office of Inspection and Enforcement bulletins, circulars, information notices, inspection and investigation notices; Licensee Event Reports; vendor reports and correspondence; Commission papers; and applicant and licensee documents and correspondence.

The following documents in the NUREG series are available for purchase from the NRC/GPO Sales Program: formal NRC staff and contractor reports, NRC-sponsored conference proceedings, and NRC booklets and brochures. Also available are Regulatory Guides, NRC regulations in the Code of Federal Regulations, and Nuclear Regulatory Commission Issuances.

Documents available from the National Technical Information Service include NUREG series reports and technical reports prepared by other federal agencies and reports prepared by the Atomic Energy Commission, forerunner agency to the Nuclear Regulatory Commission.

Documents available from public and special technical libraries include all open literature items, such as books, journal and periodical articles, and transactions. Federal Register notices, federal and state legislation, and congressional reports can usually be obtained from these libraries.

Documents such as theses, dissertations, foreign reports and translations, and non-NRC conference proceedings are available for purchase from the organization sponsoring the publication cited.

Single copies of NRC draft reports are available free, to the extent of supply, upon written request to the Division of Technical Information and Document Control, U.S. Nuclear Regulatory Commission, Washington, DC 20555.

Copies of industry codes and standards used in a substantive manner in the NRC regulatory process are maintained at the NRC Library, 7920 Norfolk Avenue, Bethesda, Maryland, and are available there for reference use by the public. Codes and standards are usually copyrighted and may be purchased from the originating organization or, if they are American National Standards, from the American National Standards Institute, 1430 Broadway, New York, NY 10018.

\section{DO NOT MICROFILM COVER}




\section{DISCLAIMER}

This report was prepared as an account of work sponsored by an agency of the United States Government. Neither the United States Government nor any agency Thereof, nor any of their employees, makes any warranty, express or implied, or assumes any legal liability or responsibility for the accuracy, completeness, or usefulness of any information, apparatus, product, or process disclosed, or represents that its use would not infringe privately owned rights. Reference herein to any specific commercial product, process, or service by trade name, trademark, manufacturer, or otherwise does not necessarily constitute or imply its endorsement, recommendation, or favoring by the United States Government or any agency thereof. The views and opinions of authors expressed herein do not necessarily state or reflect those of the United States Government or any agency thereof. 


\section{DISCLAIMER}

Portions of this document may be illegible in electronic image products. Images are produced from the best available original document. 
NUREG-0725

Rev. 5

\section{Public Information Circular for Shipments of Irradiated Reactor Fuel}

Manuscript Completed: June 1985

Date Published: June 1985

Division of Safeguards

Office of Nuclear Material Safety and Safeguards

U.S. Nuclear Regulatory Commission

Washington, D.C. 20555

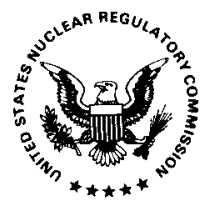




\section{NOTICE}

\section{Availability of Reference Materials Cited in NRC Publications}

Most documents cited in NRC publications will be available from one of the following sources:

1. The NRC Public Document Room, 1717 H Street, N.W. Washington, DC 20555

2. The Superintendent of Documents, U.S. Government Printing Office, Post Office Box 37082 , Washington, DC 20013.7982

3. The National Technical Information Service, Springfield, VA 22161

Although the listing that follows represents the majority of documents cited in NRC publications, it is not intended to be exhaustive.

Referenced documents available for inspection and copying for a fee from the NRC Public Document Room include NRC correspondence and internal NRC memoranda; NRC Office of Inspection and Enforcement bulletins, circulars, information notices, inspection and investigation notices; Licensee Event Reports; vendor reports and correspondence; Commission papers; and applicant and licensee documents and correspondence.

The following documents in the NUREG series are available for purchase from the NRC/GPO Sales Program: formal NRC staff and contractor reports, NRC-sponsored conference proceedings, and NRC booklets and brochures. Also available are Regulatory Guides, NRC regulations in the Code of Federal Regulations, and Nuclear Regulatory Commission /ssuances.

Documents available from the National Technical Information Service include NUREG series reports and technical reports prepared by other federal agencies and reports prepared by the Atomic Energy Commission, forerunner agency to the Nuclear Regulatory Commission.

Documents available from public and special technical libraries include all open literature items, such as books, journal and periodical articles, and transactions. Federal Register notices, federal and state legislation, and congressional reports can usually be obtained from these libraries.

Documents such as theses, dissertations, foreign reports and translations, and non-NRC conference proceedings are available for purchase from the organization sponsoring the publication cited.

Single copies of NRC draft reports are available free, to the extent of supply, upon written request to the Division of Technical Information and Document Control, U.S. Nuclear Regulatory Commission, Washington, DC 20555.

Copies of industry codes and standards used in a substantive manner in the NRC regulatory process are maintained at the NRC Library, 7920 Norfolk Avenue, Bethesda, Maryland, and are available there for reference use by the public. Codes and standards are usually copyrighted and may be purchased from the originating organization or, if they are American National Standards, from the American National Standards Institute, 1430 Broadway, New York, NY 10018. 


\section{PREFACE}

This circular has been prepared in response to numerous requests for information regarding routes for the shipment of irradiated reactor (spent) fuel subject to regulation by the Nuclear Regulatory Commission (NRC). The NRC staff approves such routes prior to their first use, in accordance with the regulatory provisions of 10 CFR Part 73.37. The objective of the safeguards regulations contained in 10 CFR Part 73.37 is to provide protection against radioactive dispersal caused by malevolent acts by persons. The design and construction of the casks used to ship the spent fuel provide adequate radiological protection of the public health and safety against accidents. Therefore, transporting appropriately packaged spent fuel over existing rail systems and via any highway system is radiologically safe without specific NRC approval of the route. However, to assure adequate planning for protection against actual or attempted acts of sabotage, the NRC requires advance route approval. This approval is given on a shipment-by-shipment or series basis, it is not a general approval of the route for subsequent spent fuel shipments.

Spent fuel shipment routes, primarily for road transportation, but also including three rail routes, are indicated on reproductions of road maps. Also included are the amounts of material shipped during the approximate 6-year period that safeguards regulations have been effective. This information is current as of June 1, 1985.

Section 147 of Public Law 96-295 provides that "...the public disclosure of information pertaining to the routes and quantities of shipments of... irradiated nuclear reactor fuel" shall not be prohibited. The maps and tables dealing with the spent fuel shipment routes and quantities included in this document are intended to facilitate the public disclosure of spent fuel shipment information. In addition, the Commission has chosen to provide information in this document regarding the NRC's safety and safeguards regulations for spent fuel shipments as well as safeguards incidents regarding spent fuel shipments (of which none have been reported to date). This additional information is furnished by the Commission in order to convey to the public a more complete picture of NRC regulatory practices concerning the shipment of spent fuel than could be obtained by the publication of the shipment routes and quantities alone.

The enclosed route information reflects approvals that have been granted in response to specific requests for shipments of spent fuel. It is not published to be used by carriers for authority to ship other categories of nuclear waste or other materials. 
PREFACE. ...............................

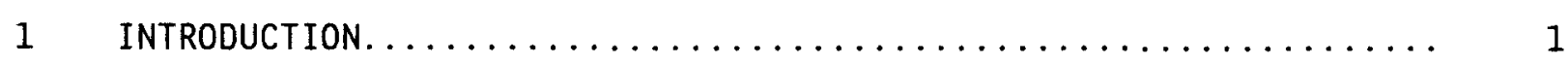

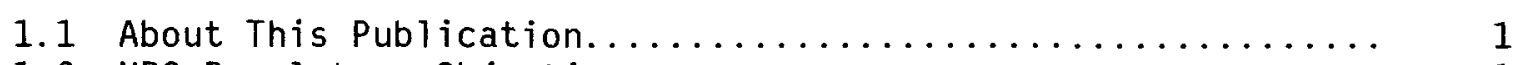

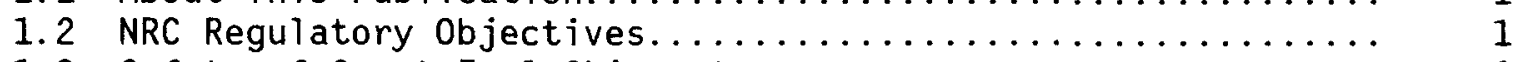

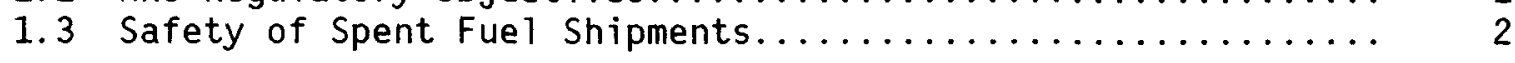

2 SAFEGUARDS FOR SPENT FUEL SHIPMENTS $\ldots \ldots \ldots \ldots \ldots \ldots \ldots \ldots \ldots \ldots$

2.1 Safeguards Incident Reporting Requirements.............. 3

2.2 Safeguards Incidents Reported..................... 3

3 APPROVED ROUTES FOR SPENT FUEL SHIPMENTS............... 3

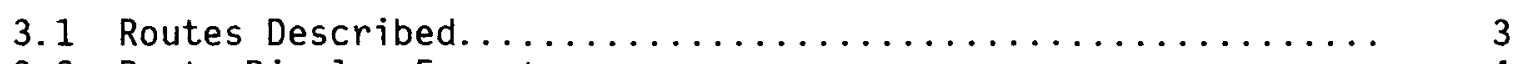

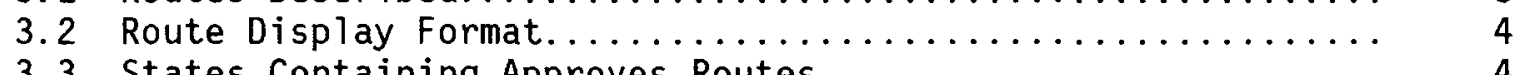

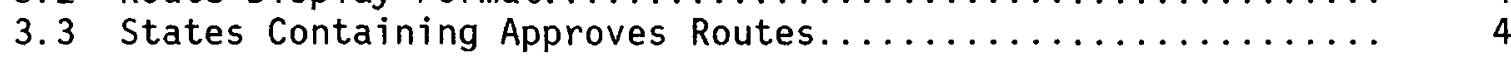

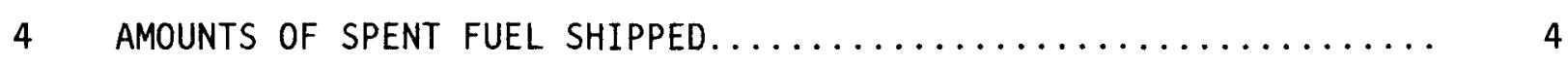

APPENDIX A - SPENT FUEL SHIPMENT ROUTES BY STATE

United States (Contiguous) ........................... A-1

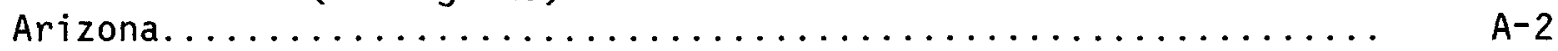

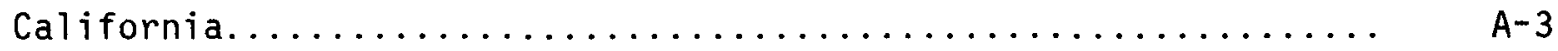

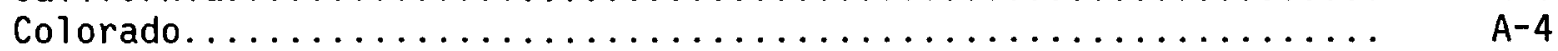

Connecticut................................

Idaho............................. $A$

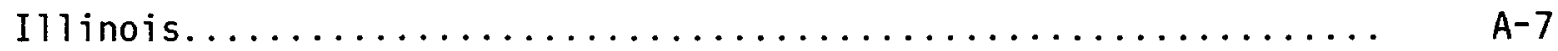

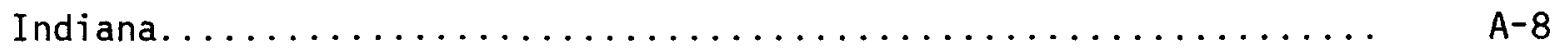

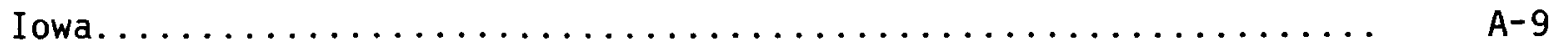

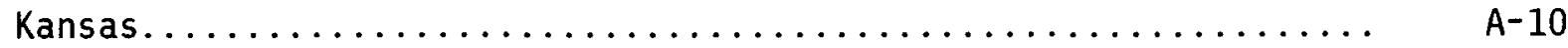

Kentucky............................. A-11

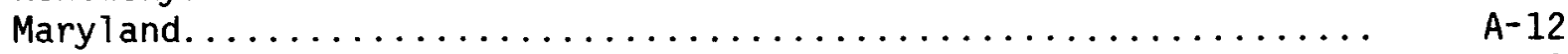

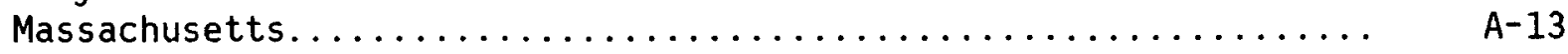

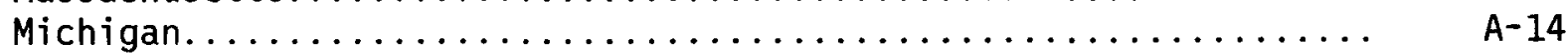

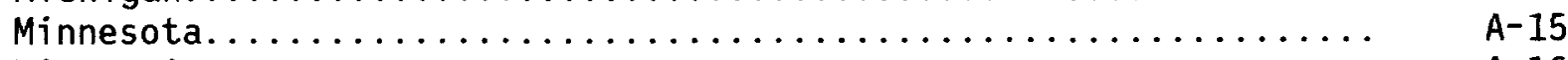

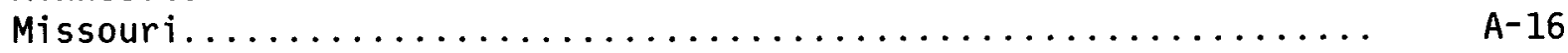

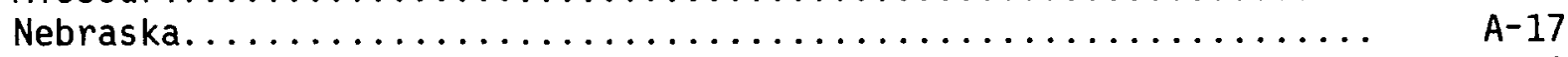

Nevada......................................

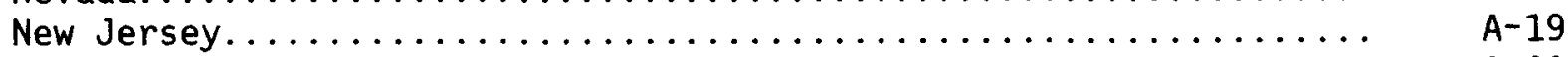

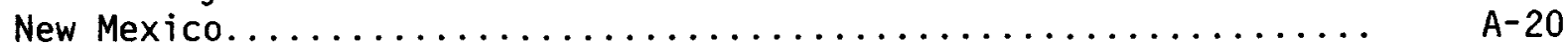

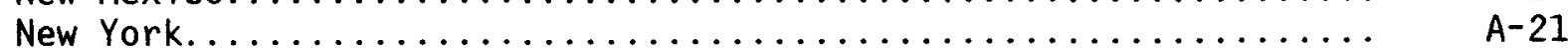

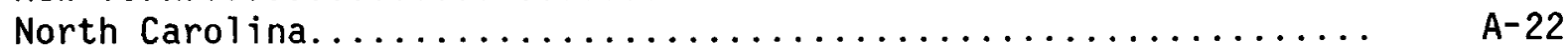

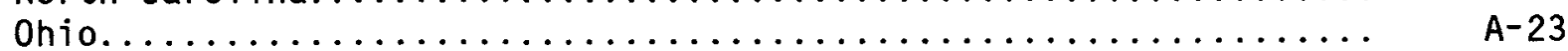

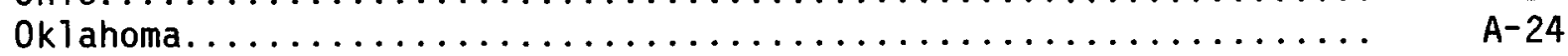

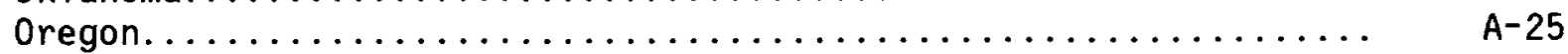

Pennsylvania.............................. A-26 


\section{INTRODUCTION}

\subsection{About This Publication}

This publication is the sixth in a series of annual publications issued by the Nuclear Regulatory Commission in response to public information requests regarding the Commission's regulation of shipments of irradiated reactor fuel.

This publication contains basically three kinds of information.

(1) Routes recently approved (18 months) by the Commission for the shipment of irradiated reactor fue 1 .

(2) Information regarding any safeguards-significant incidents which have been reported during shipments along such routes, and

(3) Cumulative amounts of material shipped.

\subsection{NRC Regulatory Objectives}

The Nuclear Regulatory Commission is authorized under the Atomic Energy Act of 1954, as amended, to regulate the private nuclear industry for purposes of protecting the public health and safety and the common defense and security of the United States. The Commission is concerned with the transportation of all nuclear materials in the nuclear fuel cycle, which includes the transportation of irradiated reactor fuel (spent fuel).

Protection of the public, insofar as the transportation of spent fuel is concerned, depends on maintaining the integrity of the shipping casks in which the spent fuel is transported. As long as the radioactive material is kept within the casks, significant radiation doses to the public will not occur. The design of the cask is intended to provide reasonable assurance that transportation accidents, even severe ones, will not cause leakage. The NRC believes that the package design provides adequate protection so that it is safe to transport appropriately packaged spent fuel over existing rail and highway systems without specific NRC approval of the route.

Although the design of the shipping cask makes difficult the release of a significant amount of radioactive material as a result of sabotage, the NRC decided that until the possible consequences of sabotage could be evaluated more fully, protective measures in addition to reliance upon cask design are prudent. Hence, exercising prudence, the Commission approved in May 1979, for issuance in effective form, new interim regulations for strengthening the protection of shipments of spent fuel against sabotage. In May 1980, these regulations were revised in response to public comments. The interim regulations require, among other things, NRC approval of routes for the transportation of spent fuel to assure adequate planning for protection against actual or attempted acts of sabotage. Further discussion of the safety of spent fuel shipments is provided herein. 
Furthermore, the routes approved by the Commission reflect the U.S. Department of Transportation (DOT) requirements of 49 CFR Part 177.825(b), which designate the use of the Interstate System of highways as being the primary roadways over which radioactive material shipments under a route plan are to be carried. The general designation as preferred highways is given to these roadways based upon an overall performance rating with respect to the lower accident rates and their capacity for reducing transit times.

Appropriate state routing agencies, following prescribed criteria, may designate an alternative route to the preferred interstate system.

\subsection{Safety of Spent Fue1 Shipments}

The NRC distinguishes between safety regulation of shipments and safeguards regulation of shipments. Safety deals with protection against adverse consequences from accidents, or natural causes, while safeguards deals with the protection of shipments against deliberate, malevolent acts by persons.

The NRC ensures the safety of spent fuel shipments mainly through stringent packaging requirements. Spent fuel is shipped only in massive, durable casks designed to withstand severe accidents without release of the radioactive contents.

of the thousands of shipments that have been made during the past 30 years, none has resulted in an identifiable injury to the public through release of radioactive material.

General standards and requirements for spent fuel casks are set forth in NRC regulations. A cask must be designed to withstand a series of specified impact, puncture, and fire environments, thereby providing reasonable assurance that the package will withstand serious transportation accidents. The cask design is initially reviewed by the NRC staff to verify its resistance to accidents. A certificate must be issued by the NRC before a cask fabricated from that design can be used to transport spent fuel.

The standards that have been established in the regulations provide that a cask shall prevent the loss or dispersion of the radioactive contents, provide adequate shielding and heat dissipation, and prevent nuclear criticality under both normal and accident conditions of transportation. The normal conditions of transportation which must be considered are specified in the regulations in terms of hot and cold environments, pressure differential, vibration, water spray, impact, puncture, and compression tests. Accident conditions which must be Eonsidered are specified in terms of impact, puncture and fire conditions. Thus far, success of the packaging strategy has been demonstrated despite an occasional traffic accident. For example, one such accident occurred on December 8, 1970, on a major highway near 0ak Ridge, Tennessee. In this accident, the driver of a vehicle carrying a spent fuel cask swerved to avoid colliding with an oncoming vehicle, lost control, and overturned off the roadway. The cask assembly was thrown into a ditch, traveling more than 100 feet before coming to rest. No release of contents or release of radiation occurred. The outer surface of the cask suffered minor damage. The spent fuel cask was placed on another trailer and taken to its destination. The cask was returned to service following repair of the minor damage and inspection. 
The durableness of casks has also been demonstrated in controlled tests. In one DOE test, a truck bearing a cask was deliberately placed in the path of and struck by a 120 -ton locomotive traveling about $80 \mathrm{miles}$ per hour. In another DOE test, a cask aboard a truck moving at about 80 miles per hour was deliberately crashed into an immovable concrete structure. Subsequent examination confirmed in both of these tests that no radioactive material would have been released from the casks had they been loaded with spent fuel. Thus, both field experience and controlled tests have substantiated the NRC strategy of depending upon packaging design for safety in transit.

\section{SAFEGUARDS FOR SPENT FUEL SHIPMENT}

\subsection{Safeguards Incident Reporting Requirements}

Safeguards incidents for spent fuel shipments are those which involve attempts at sabotage of spent fuel, or purposeful acts which threaten or result in significant degradation of the safeguards system used to protect the shipment. Licensees are required to record such events in a written log. In addition, licensees are required to promptly report safeguards incidents to the NRC by telephone, followed by a written report. Licensees are also required under existing regulations to immediately notify local law enforcement authorities upon the occurrence or discovery of a safeguards incident for the purpose of initiating an appropriate response.

\subsection{Safeguards Incidents Reported}

To date no safeguards incidents involving the shipment of spent fuel have occurred. Also, no NRC licensee has been cited for noncompliance with spent fuel transportation safeguards regulations.

\section{APPROVED ROUTES FOR SPENT FUEL SHIPMENTS}

\section{1 Routes Described}

NRC licensees planning to ship spent fuel are required to submit proposed routes for such shipments to the NRC staff for approval prior to the first use of a given route. Once approved, the same route may be utilized for additional shipments in a proposed series of shipments without further approval of the route, provided that the NRC is notified in advance of each shipments. This approval is for a stated series of shipments, any subsequent shipments not a part of an approved series must be individually approved. The NRC approval is only for spent fuel shipments and does not include other categories of nuclear waste material. From time to time, the NRC may authorize alternate routes or detours as circumstances dictate at the time of shipment. Also, detours may be taken without prior approval in response to unforeseen circumstances which arise during a shipment. Criteria for determining when and how such detours may be taken are provided in published regulatory guidance (NUREG-0561, Rev. 1).

The spent fuel shipment routes shown in Appendix A of this document are those which were approved as of June 1, 1985. Some of these routes have been used for shipments which have already been completed, others for shipments which 
have yet to be completed, while some have been approved but have yet to be utilized. The routes shown do not include proposed routes.

\subsection{Route Display Format}

The routes are shown in the form of maps acquired from the U.S. Department of Transportation, Federal Highway Authority. Each state containing one or more approved spent fuel shipment routes is included. In some cases, to achieve the best clarity, only the portions of the state including the routes are shown. The routes are indicated by widened shaded 1 ines drawn along the routes. The route numbers have been left unshaded to assure maximum clarity.

\subsection{States Containing Approved Routes}

The states containing portions of approved spent fuel shipment routes are listed in Table 1 . In total, there are 37 states containing portions of such routes.

\section{AMOUNTS OF SPENT FUEL SHIPPED}

The approximate amounts of spent fuel (to the nearest kilogram $(\mathrm{Kg})$ ) shipped from one facility to another are presented in Table 2. Each entry corresponding to a given combination of origin and destination for which a spent fuel shipment route is approved describes the number of shipments completed between July 16, 1979 and June 1, 1985, and the total number of kilograms of spent fue 1 included in such shipments (exclusive of structural and packaging material). Since some nuclear facilities both send and receive spent fuel shipments, shipments may proceed in either direction along a given route. Accordingly, each location listed in Table 2 is considered to be alternately a point of origin or destination. Combinations of origins and destinations between which no spent fuel shipment routes are approved are indicated by the entry "NR." 
STATES CONTAINING APPROVED SPENT FUEL SHIPMENTS ROUTES

1. Arizona

2. California

3. Colorado

4. Connecticut

5. Idaho

6. Illinois

7. Indiana

8. Iowa

9. Kansas

10. Kentucky

11. Maryland

12. Massachusetts

13. Michigan

14. Minnesota

15. Missouri

16. Nebraska

17. Nevada

18. New Jersey
19. New Mexico

20. New York

21. North Carolina

22. Ohio

23. Oklahoma

24. uregon

25. Pennsylvania

26. Rhode Is land

27. South Carolina

28. Tennessee

29. Texas

30. Utah

31. Vermont

32. Virginia

33. Washington

34. Wiscons in

35. West Virginia

36. Wyoming 
Table 2 NUMBER/QUANTITY OF SHIPMENTS (NUMBER/KILOGRAMS)

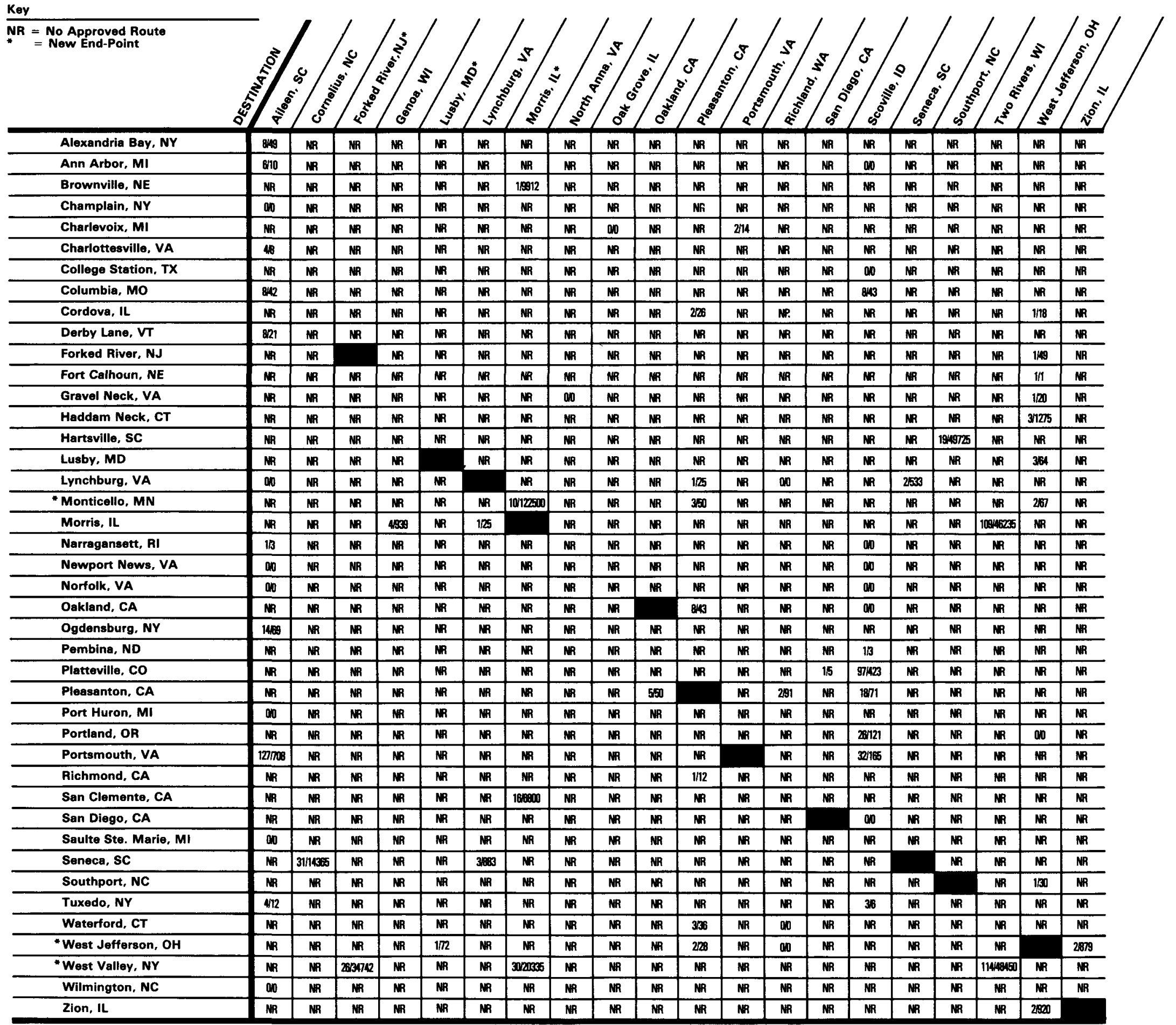




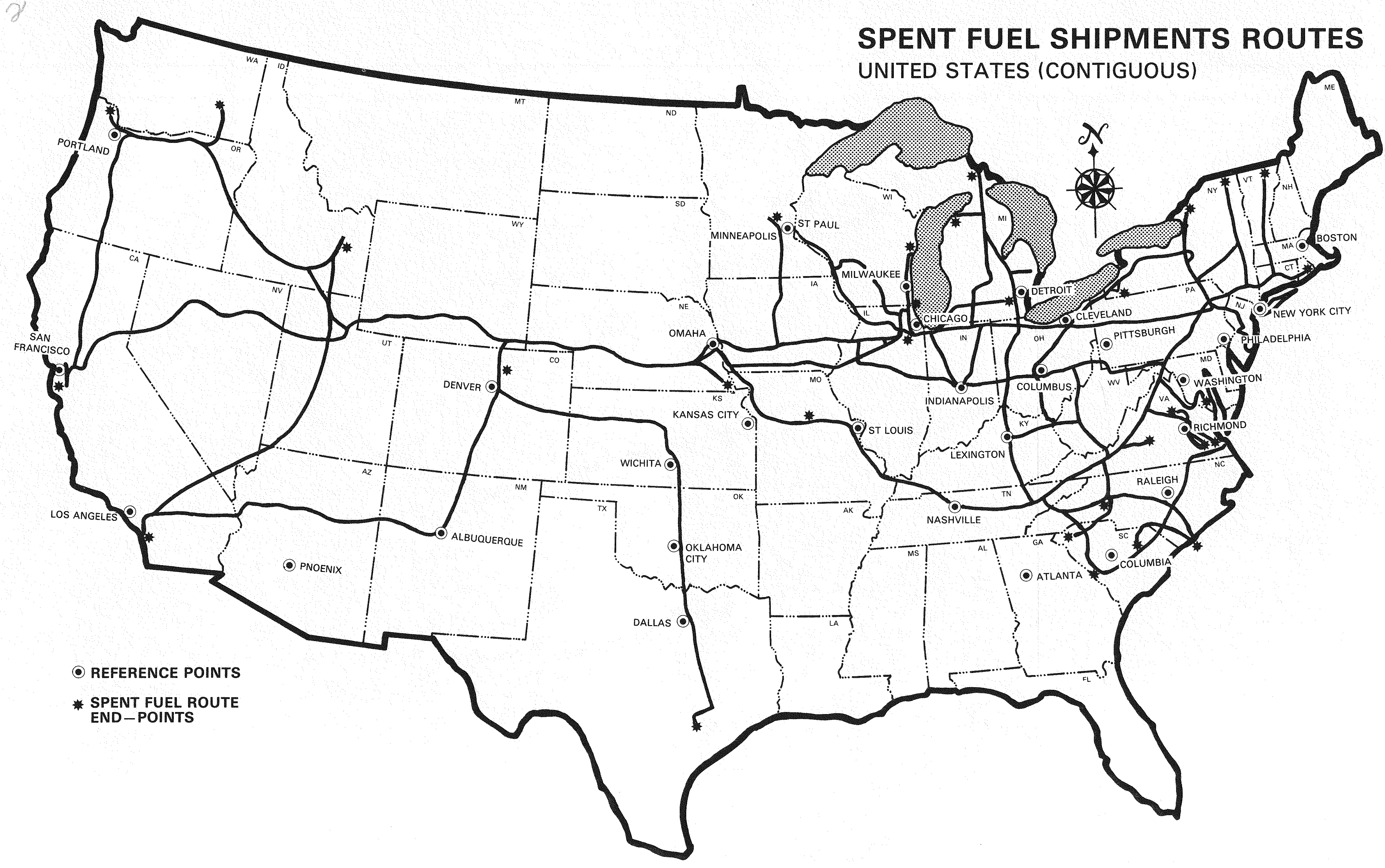




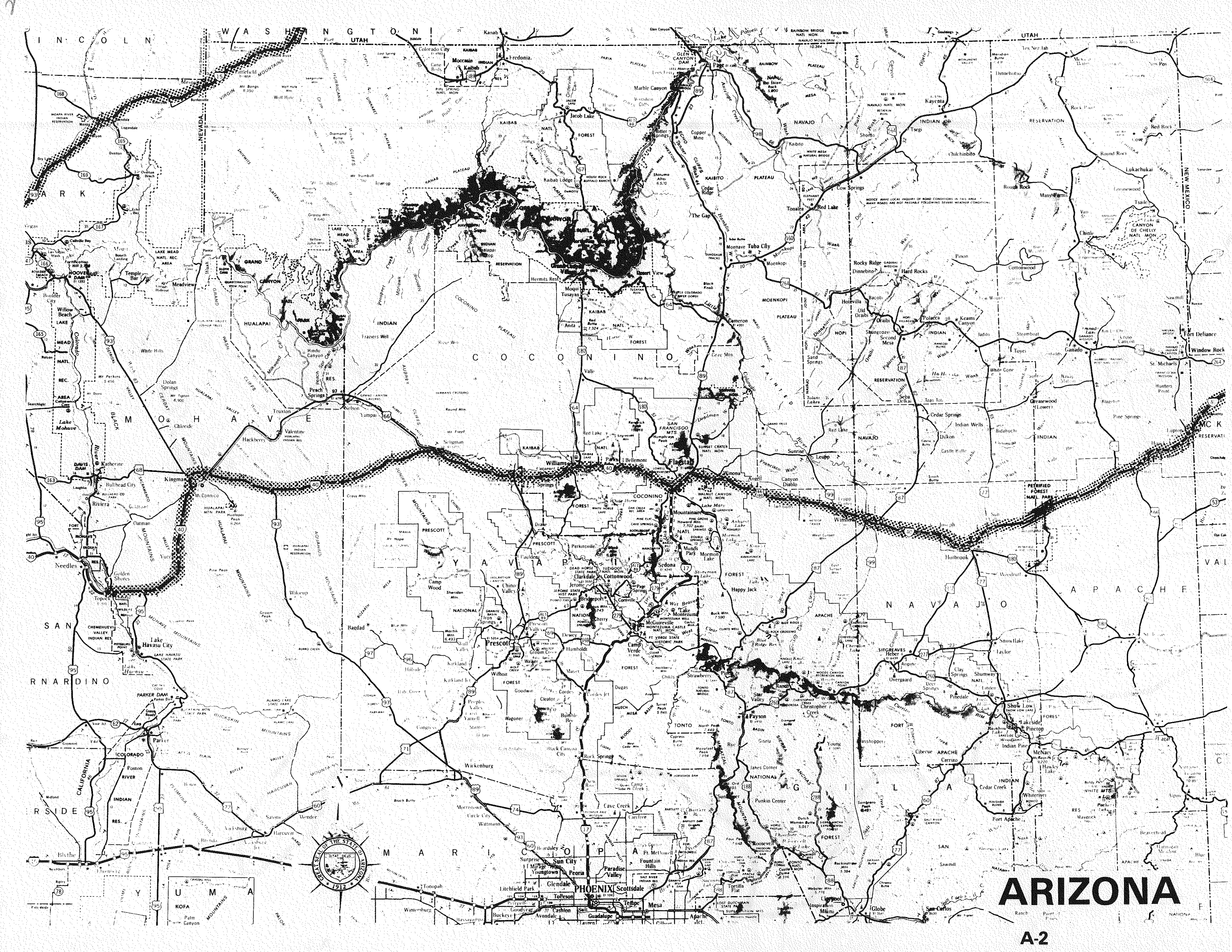




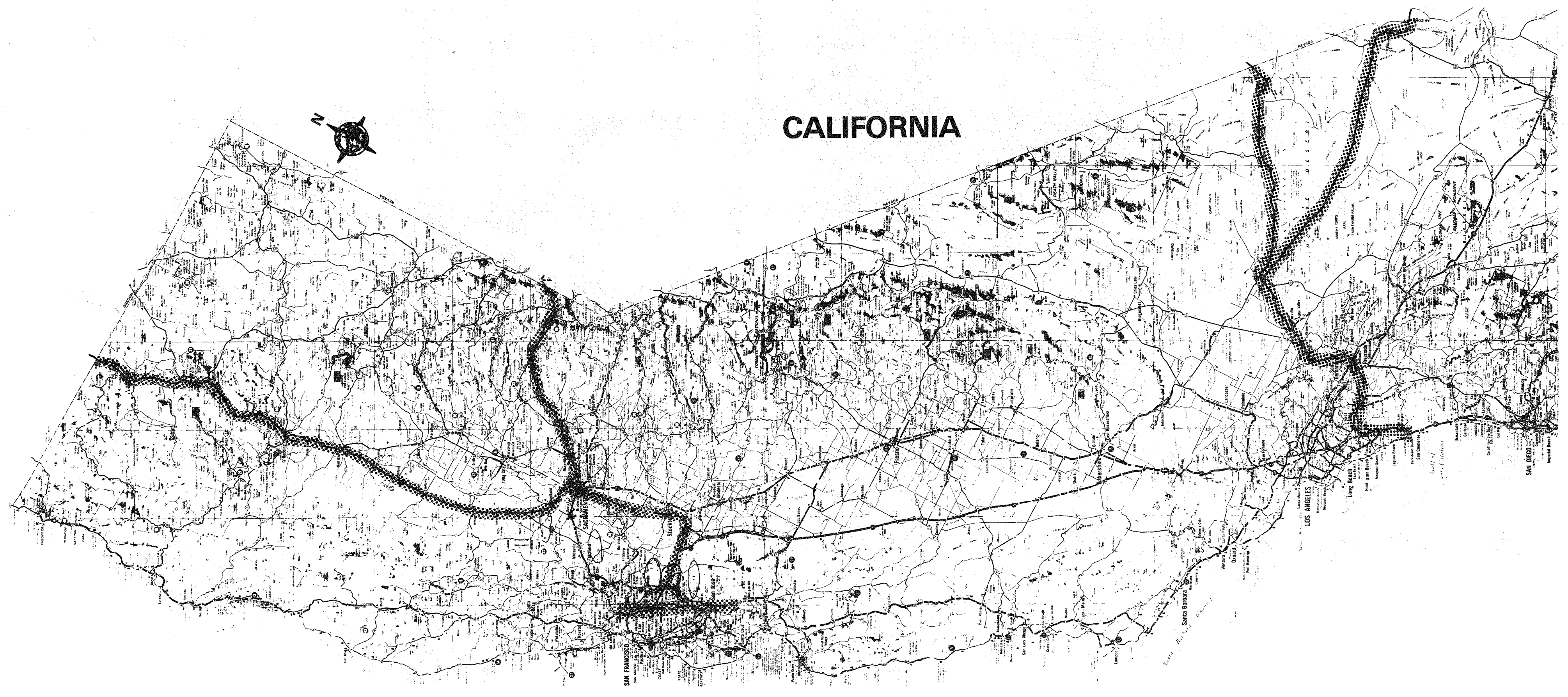




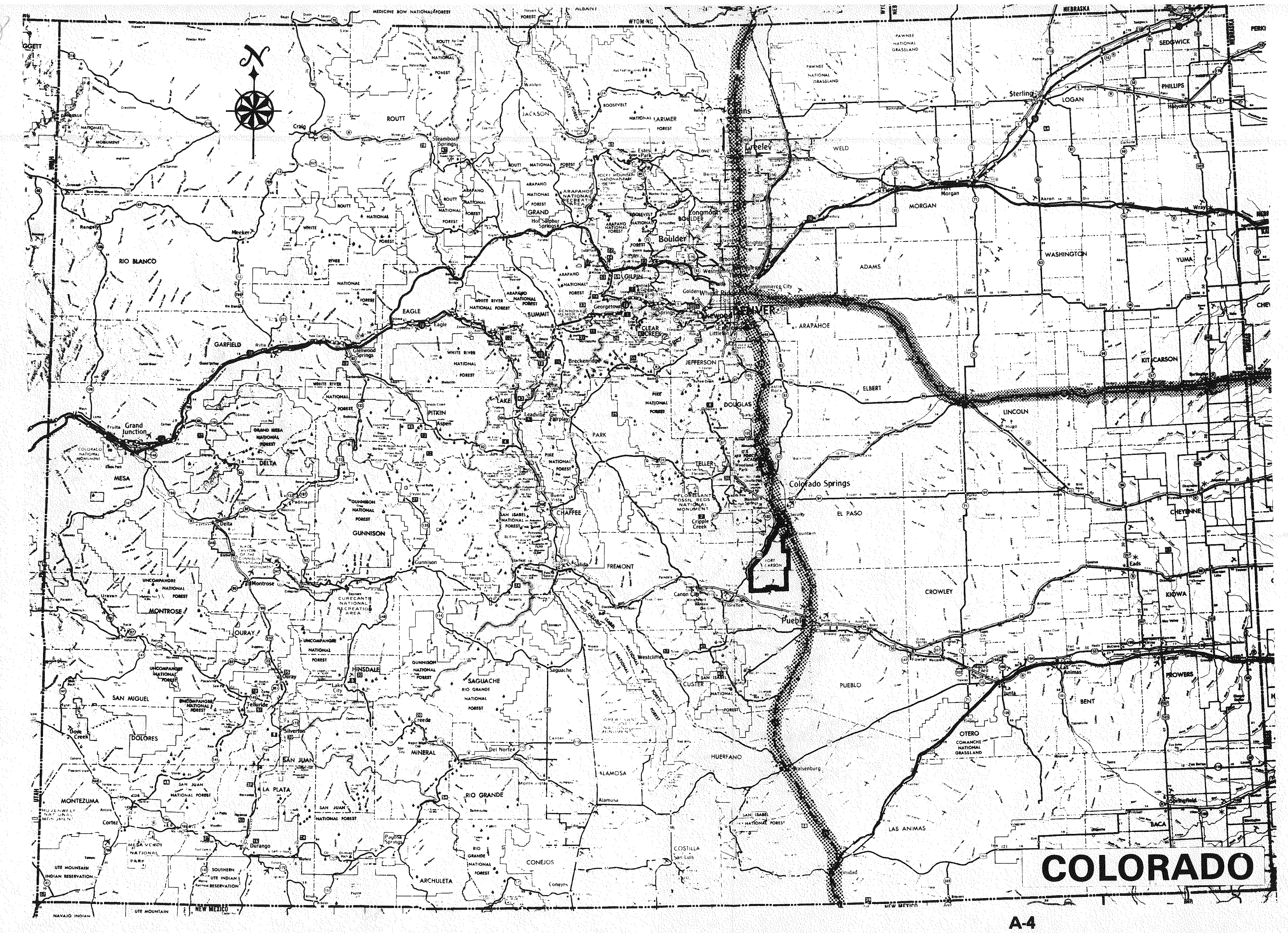









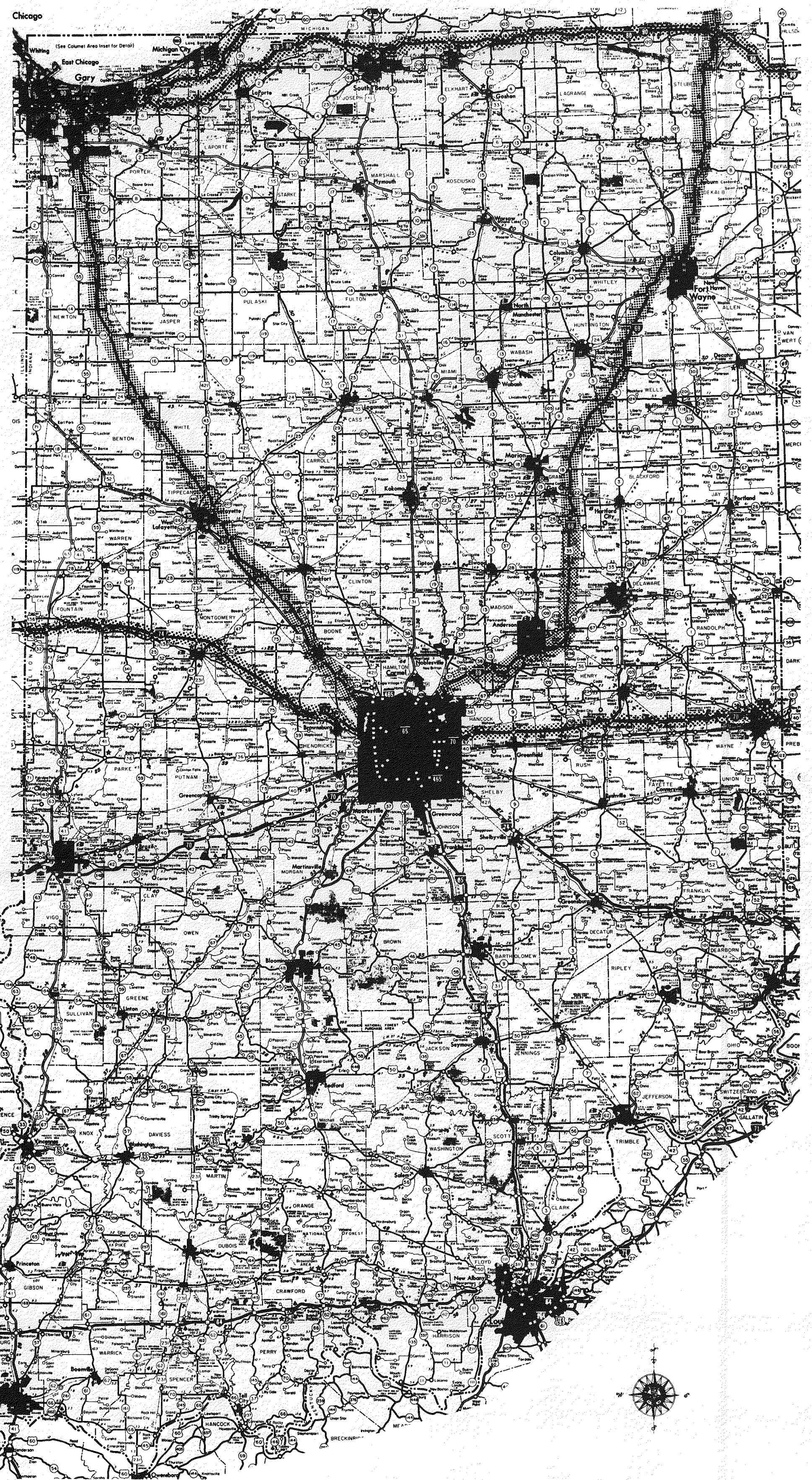

INDIANA 


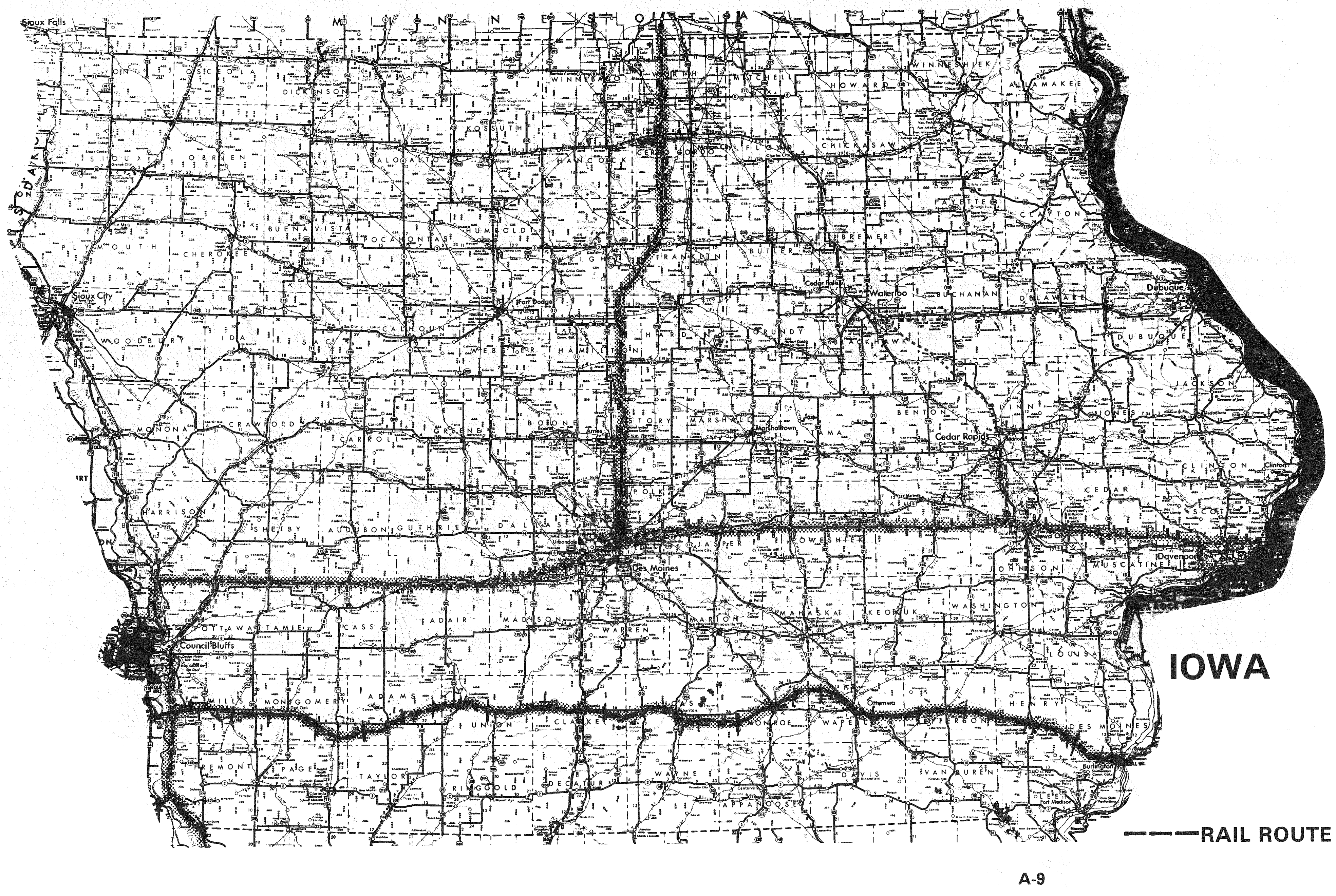









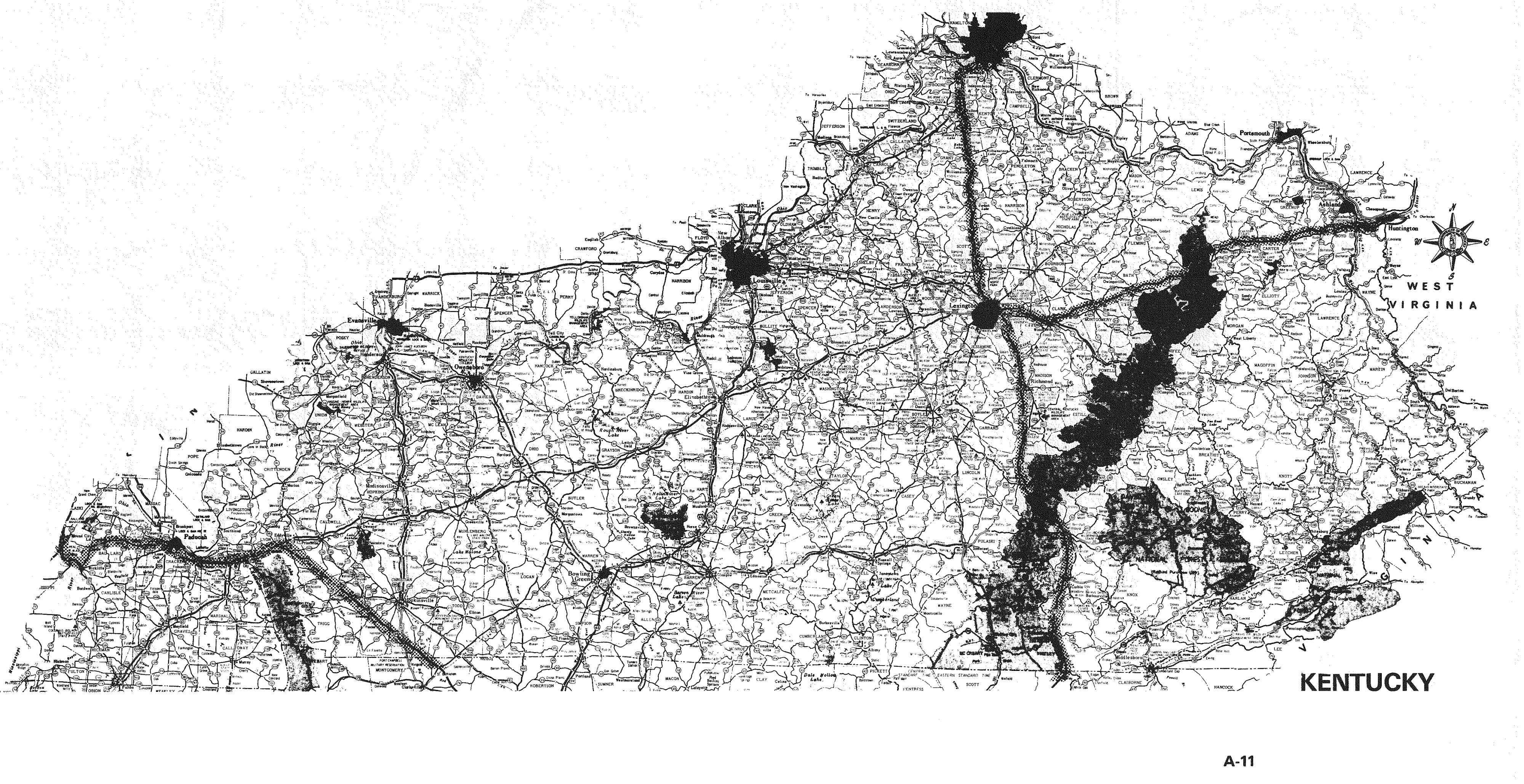









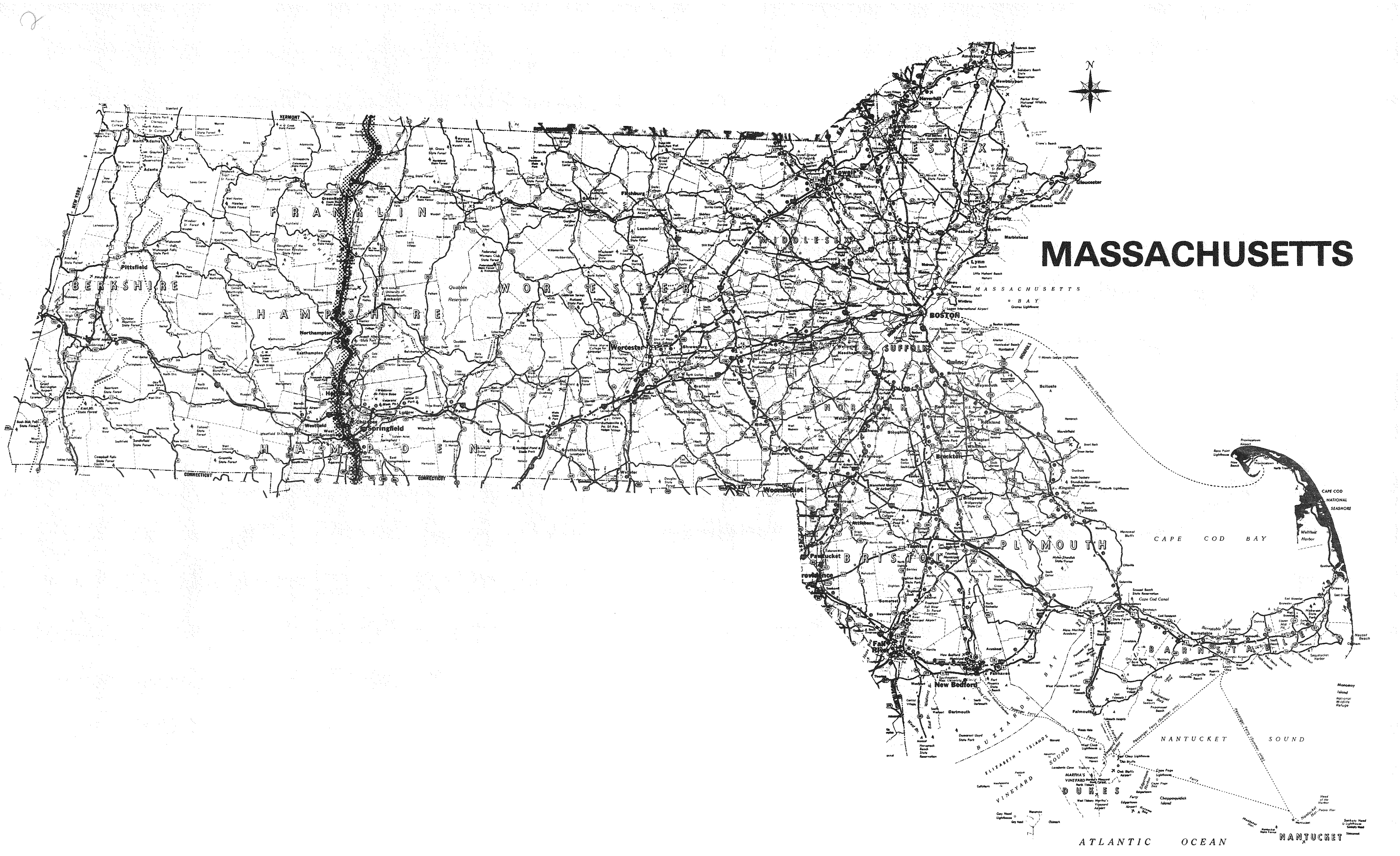



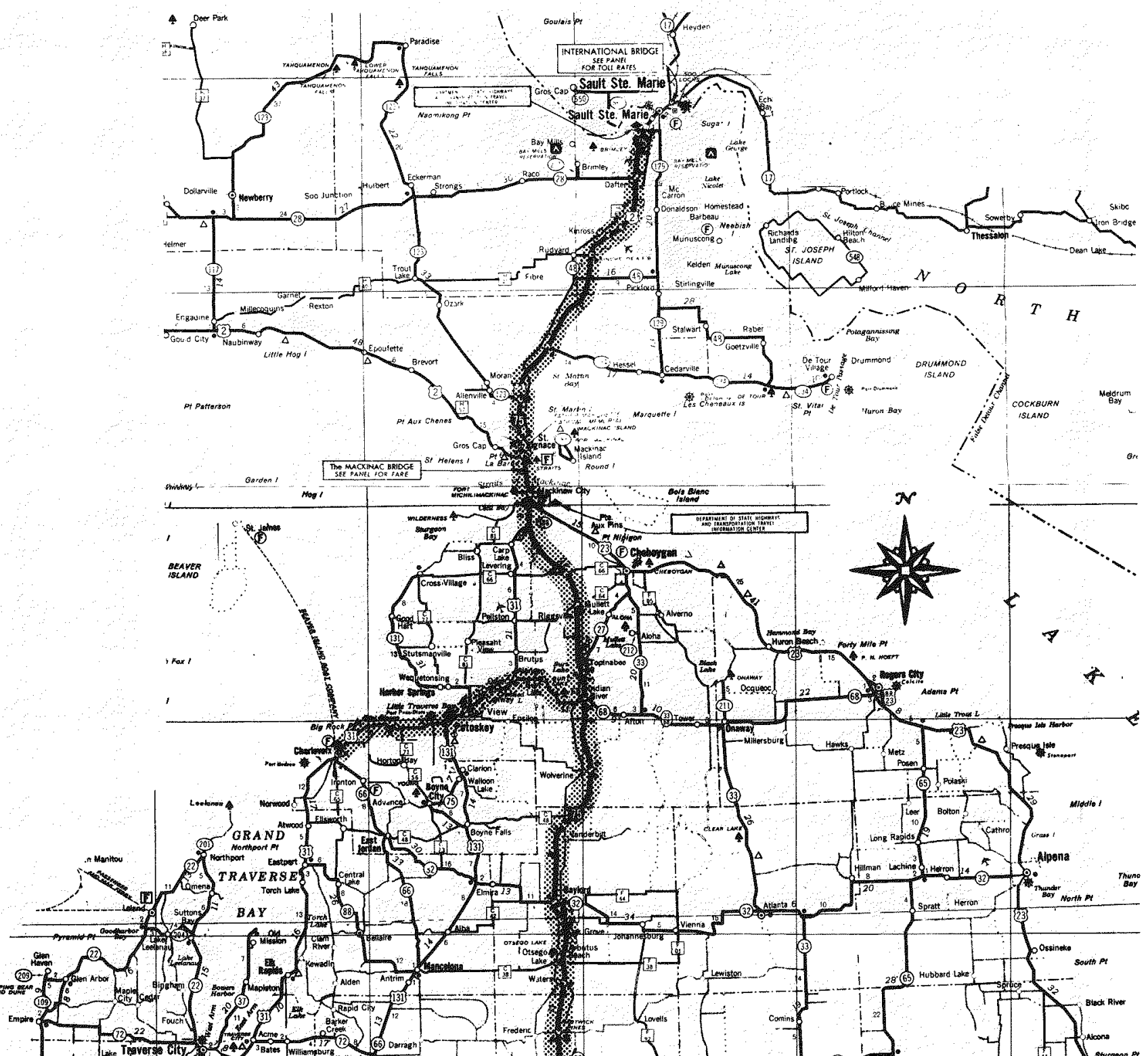

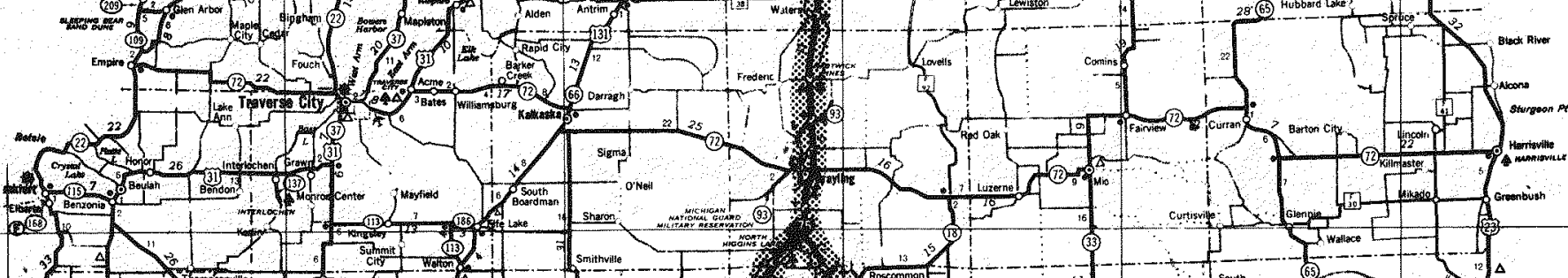

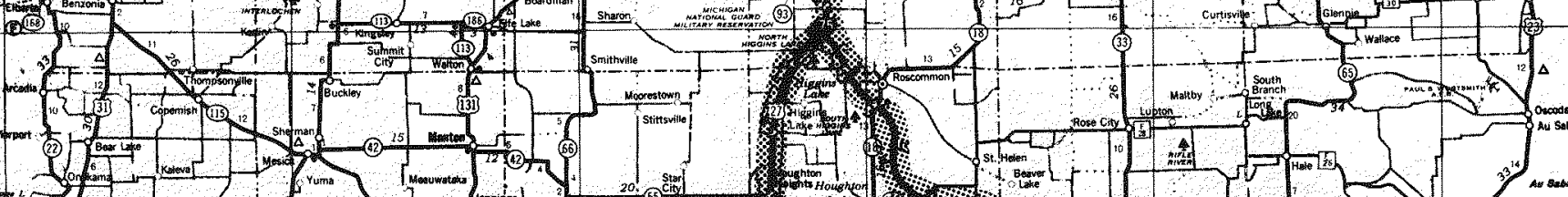
(15) (1)

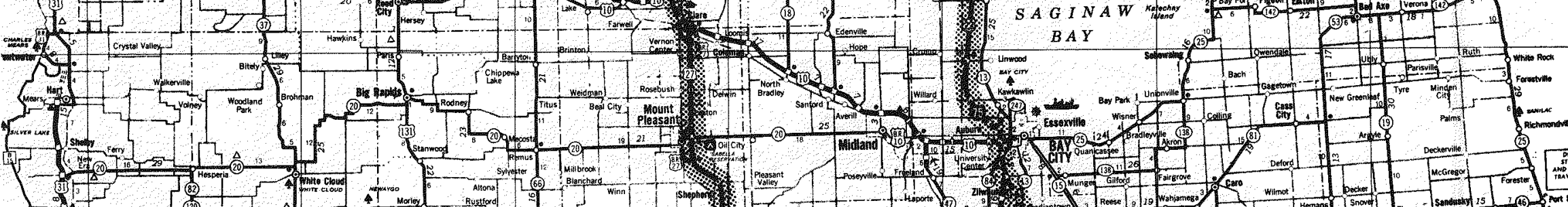
2015)

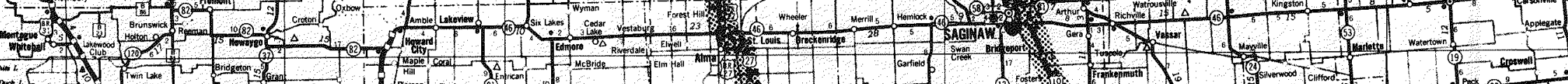

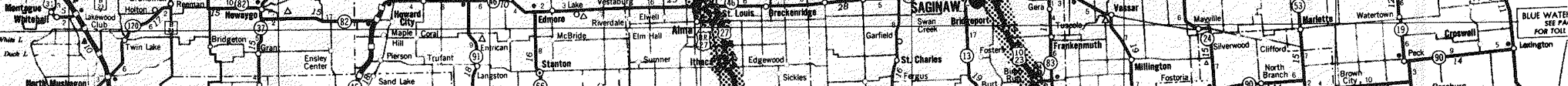

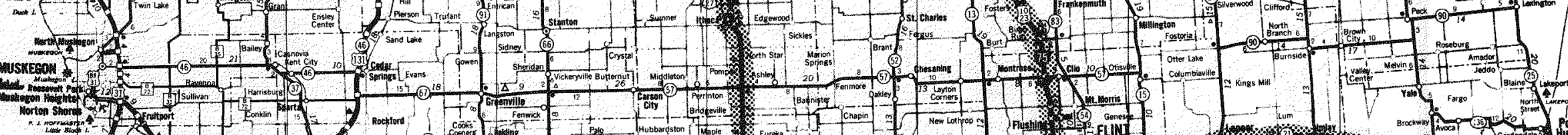

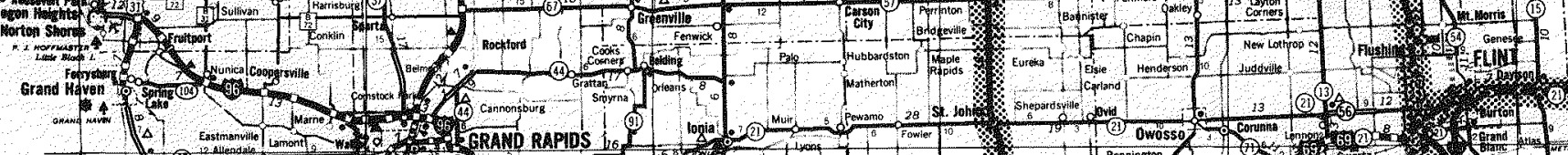

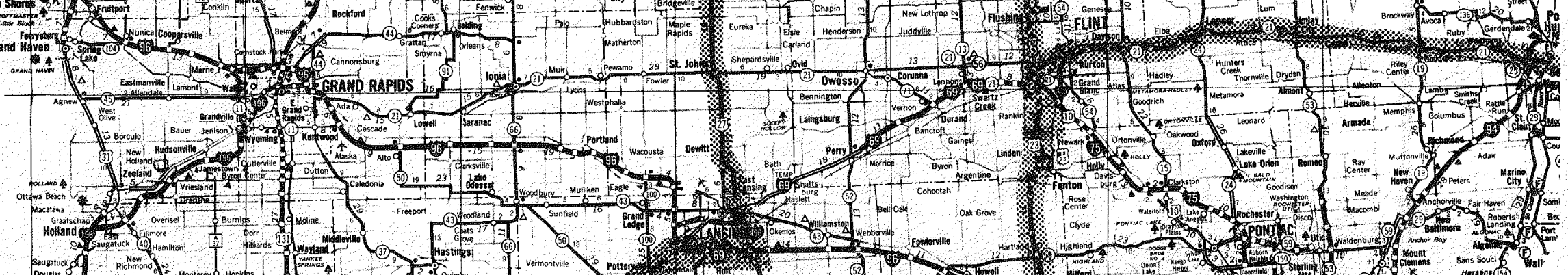

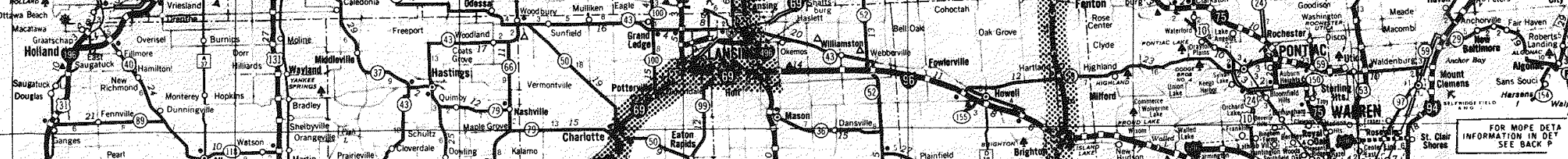
(1)

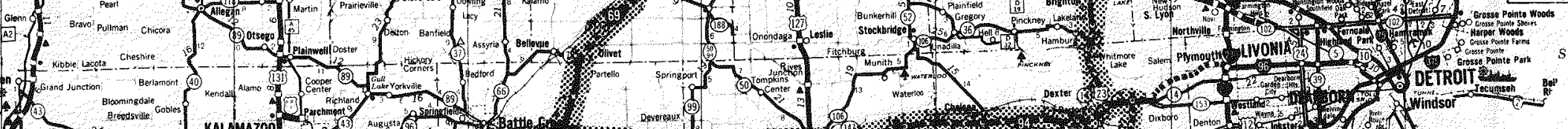

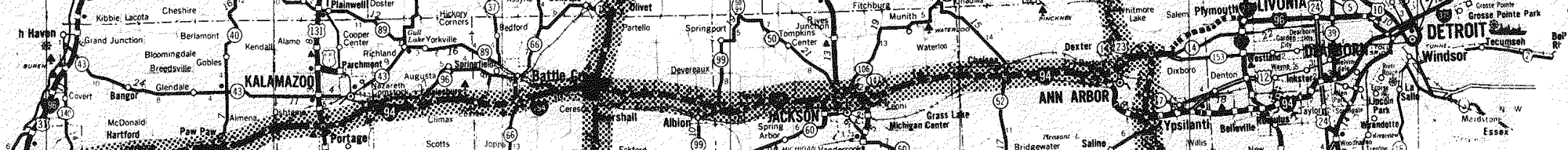

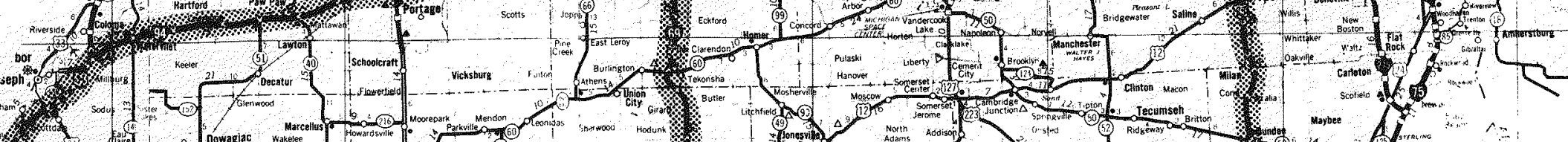
MICHIGAN 2at 


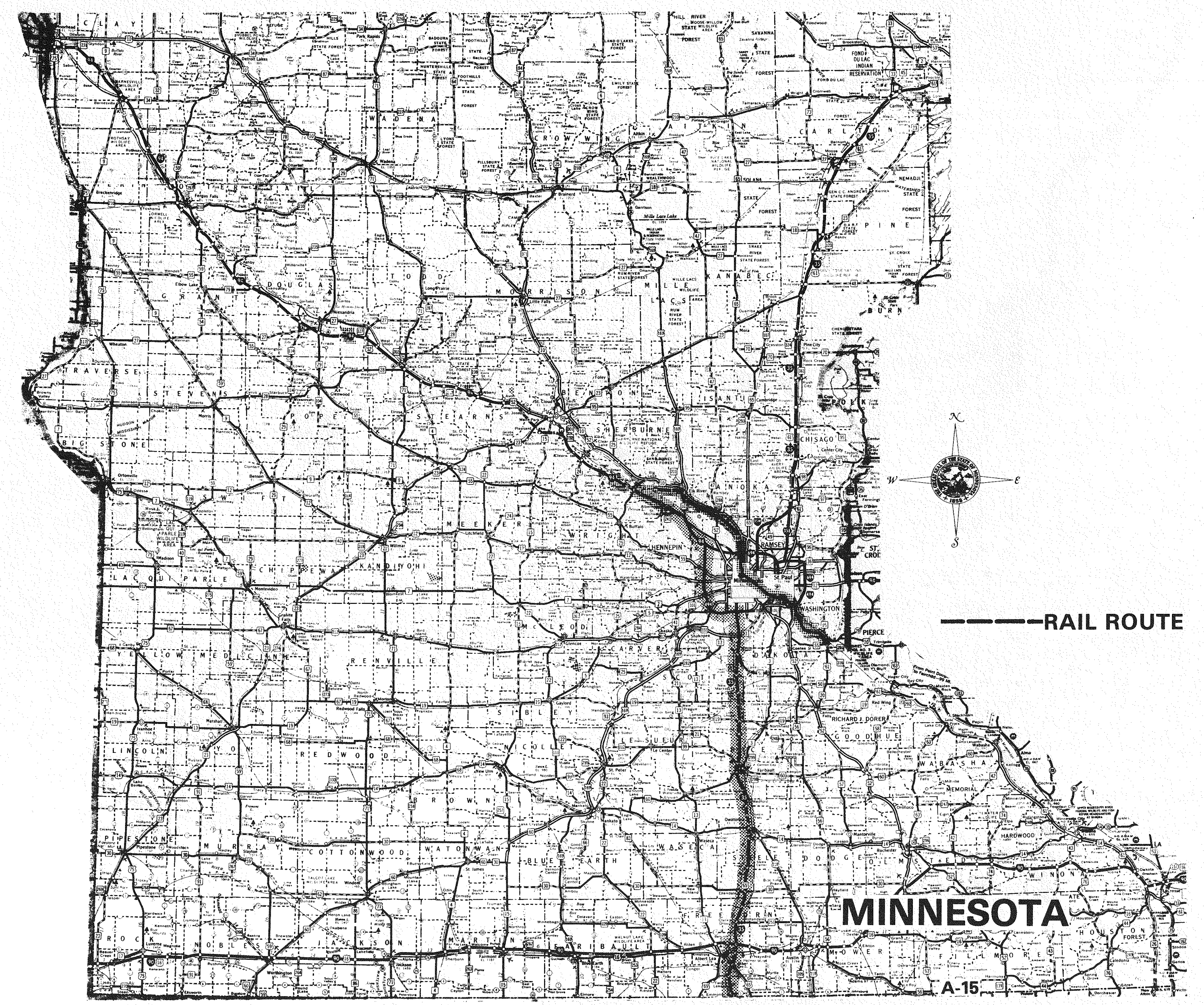




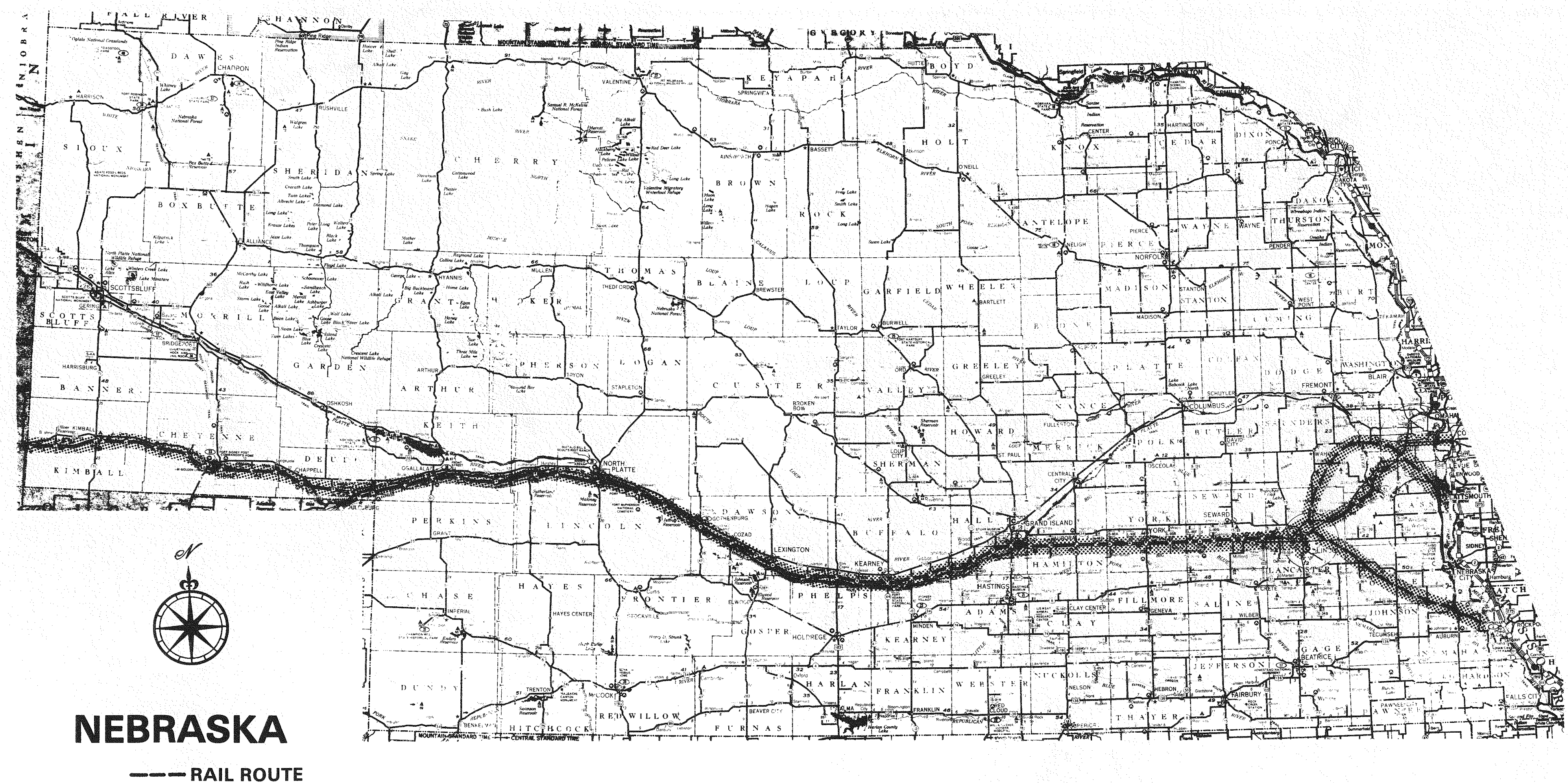




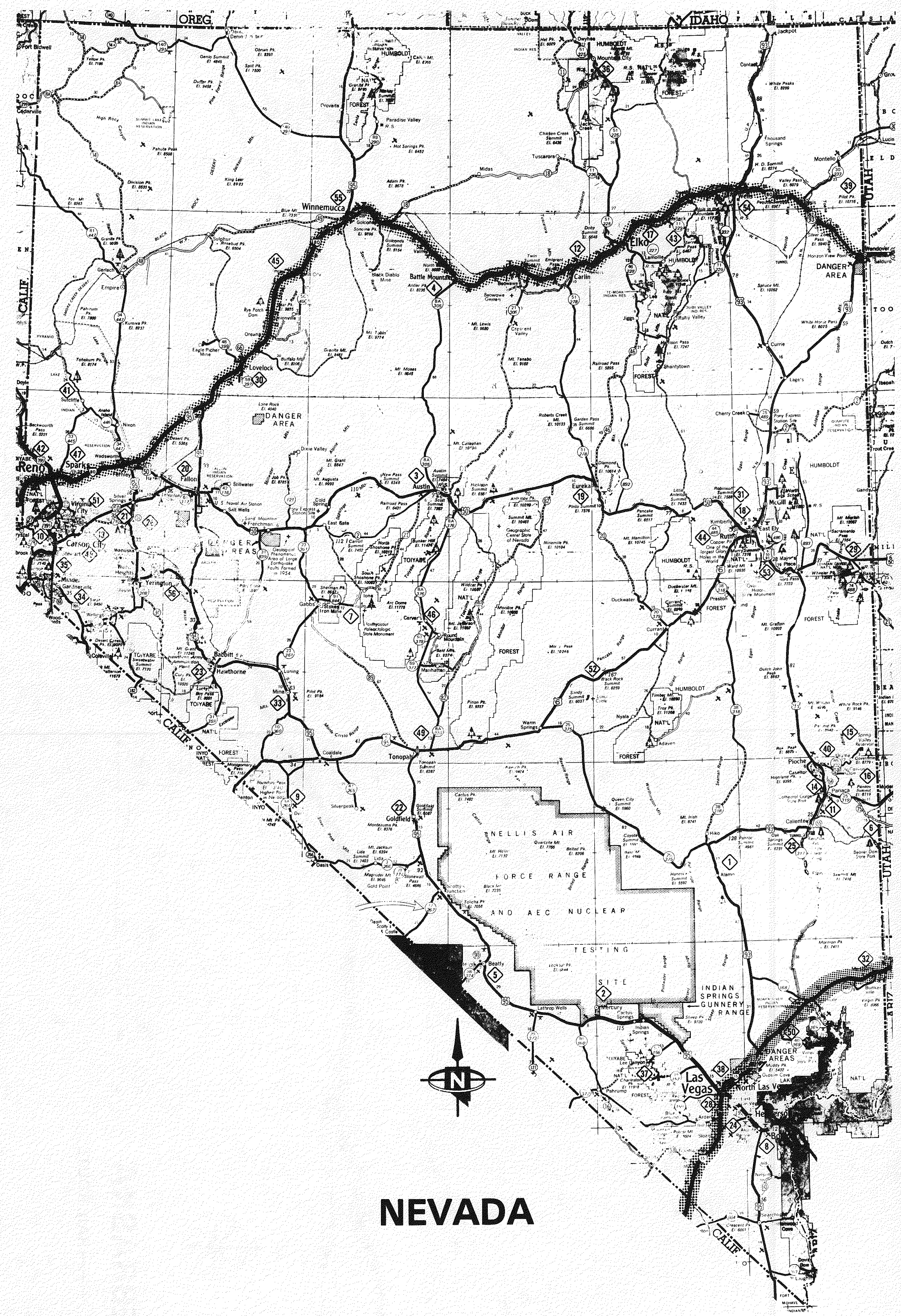




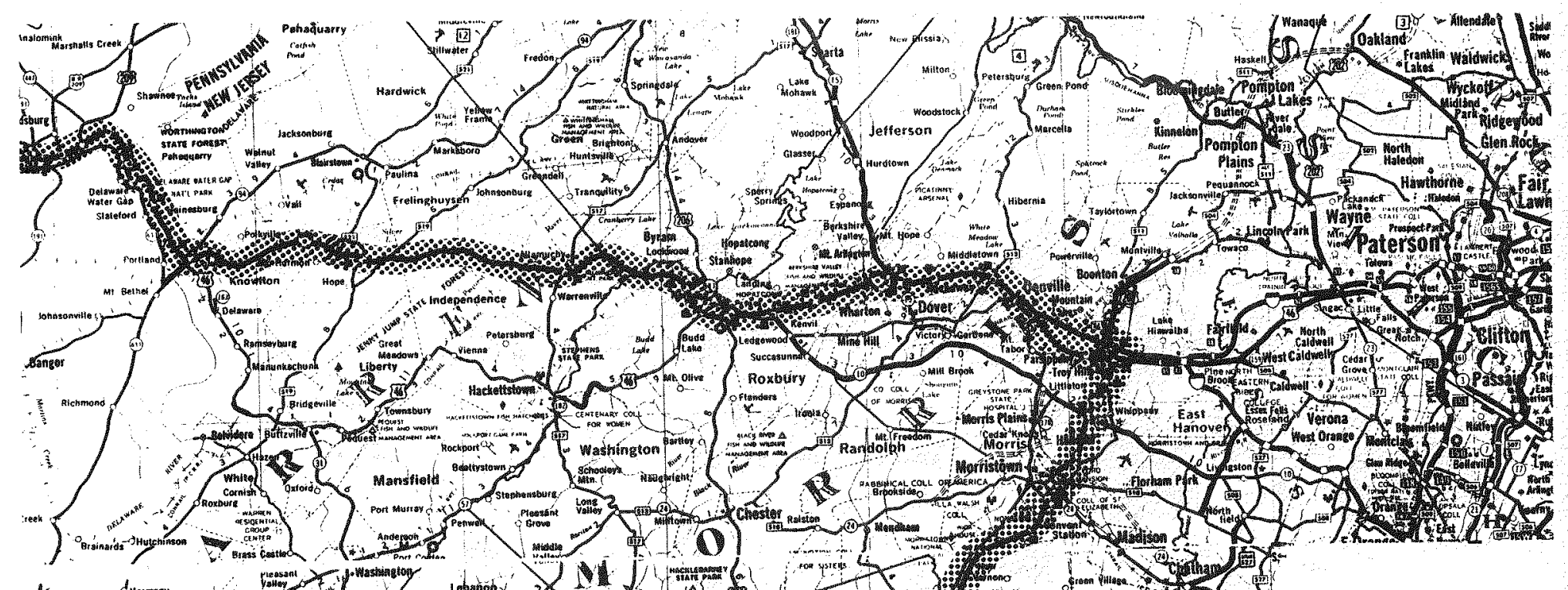

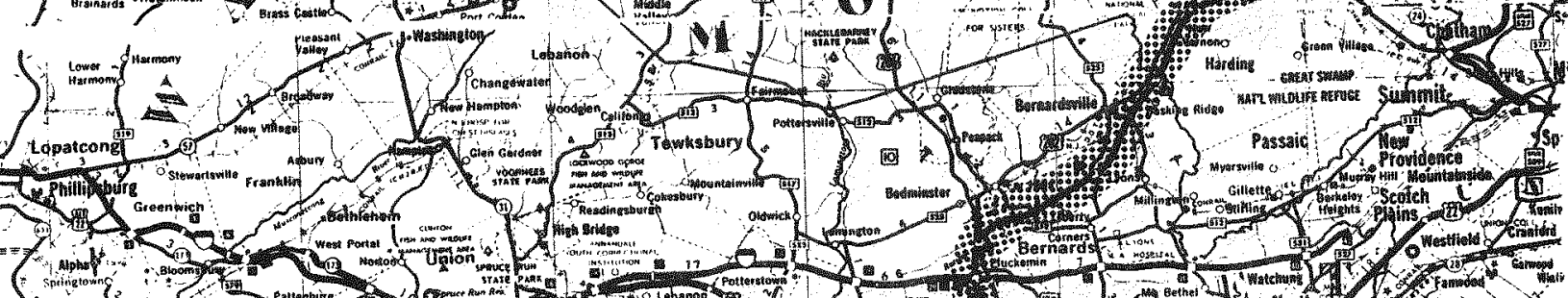

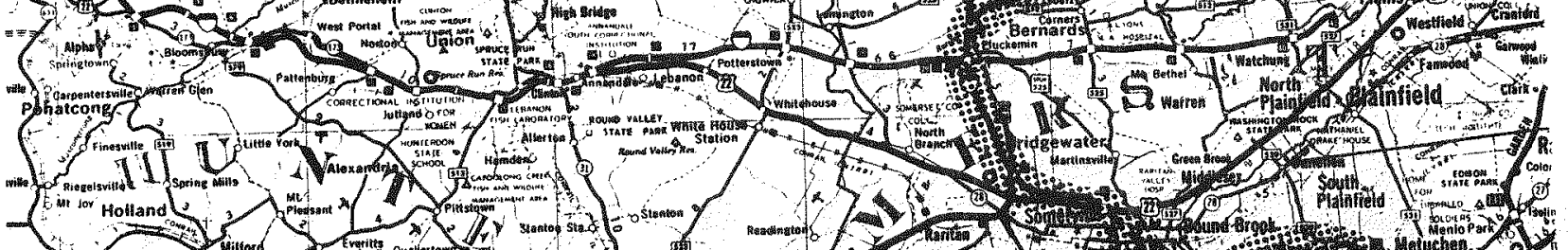
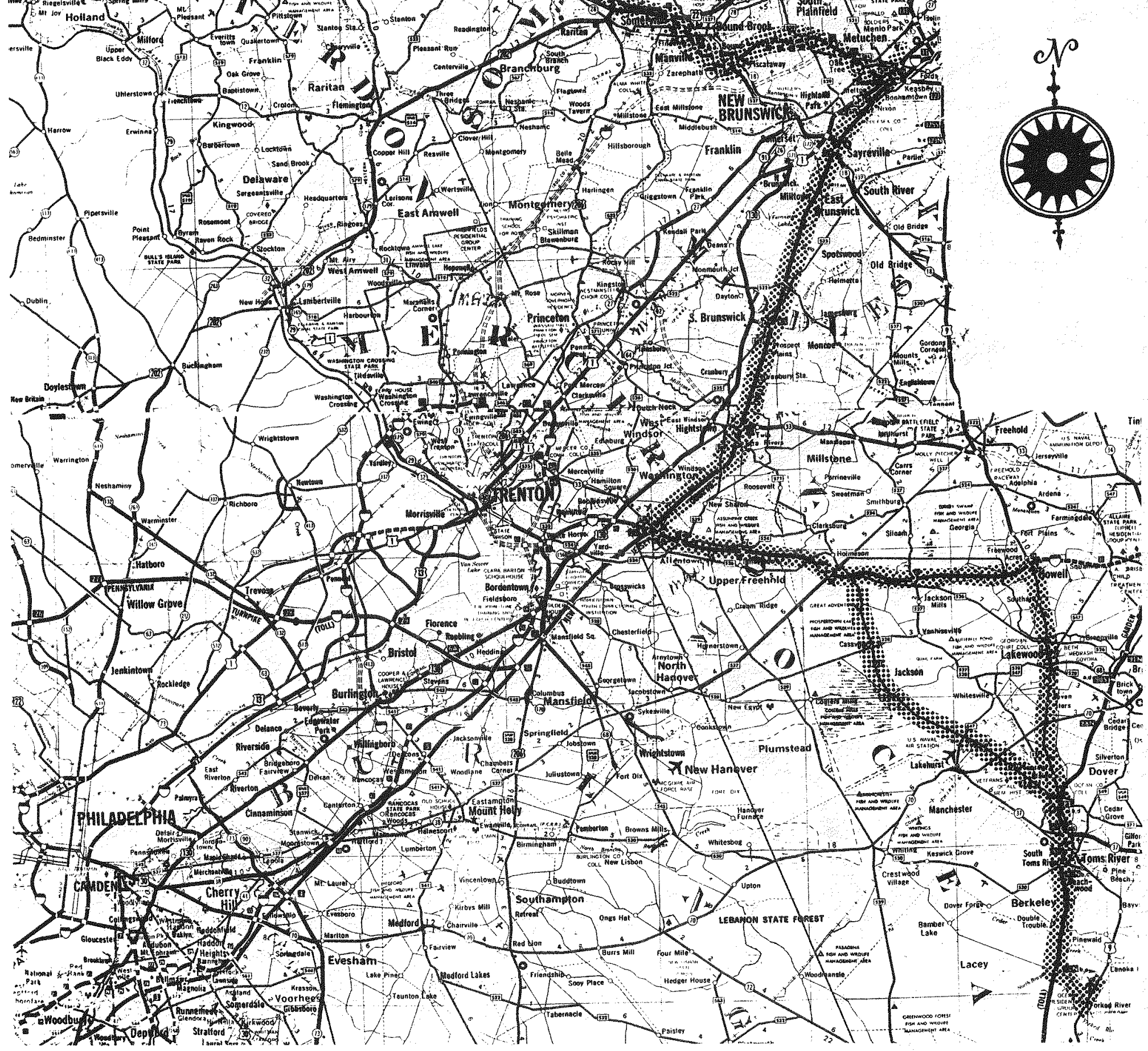


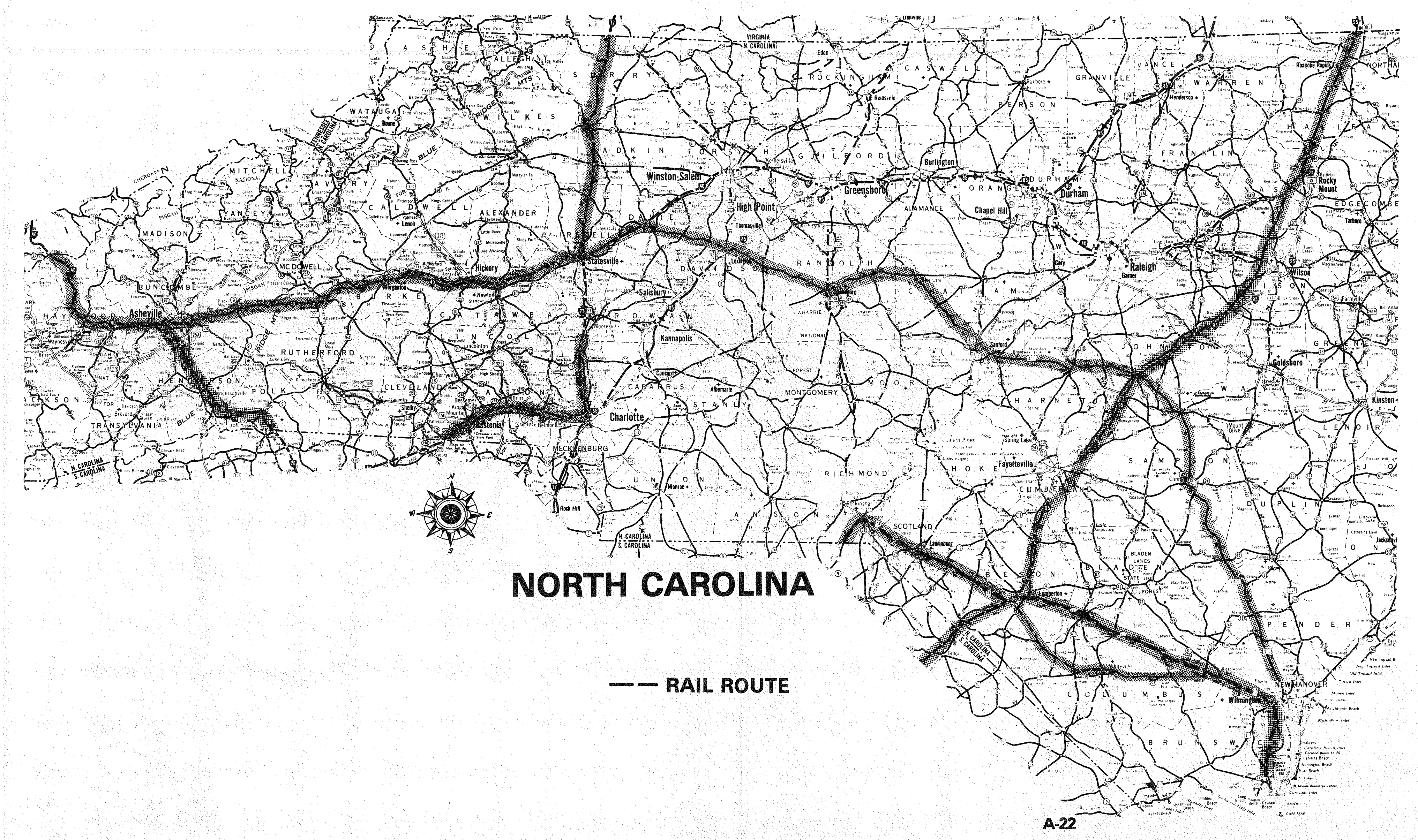









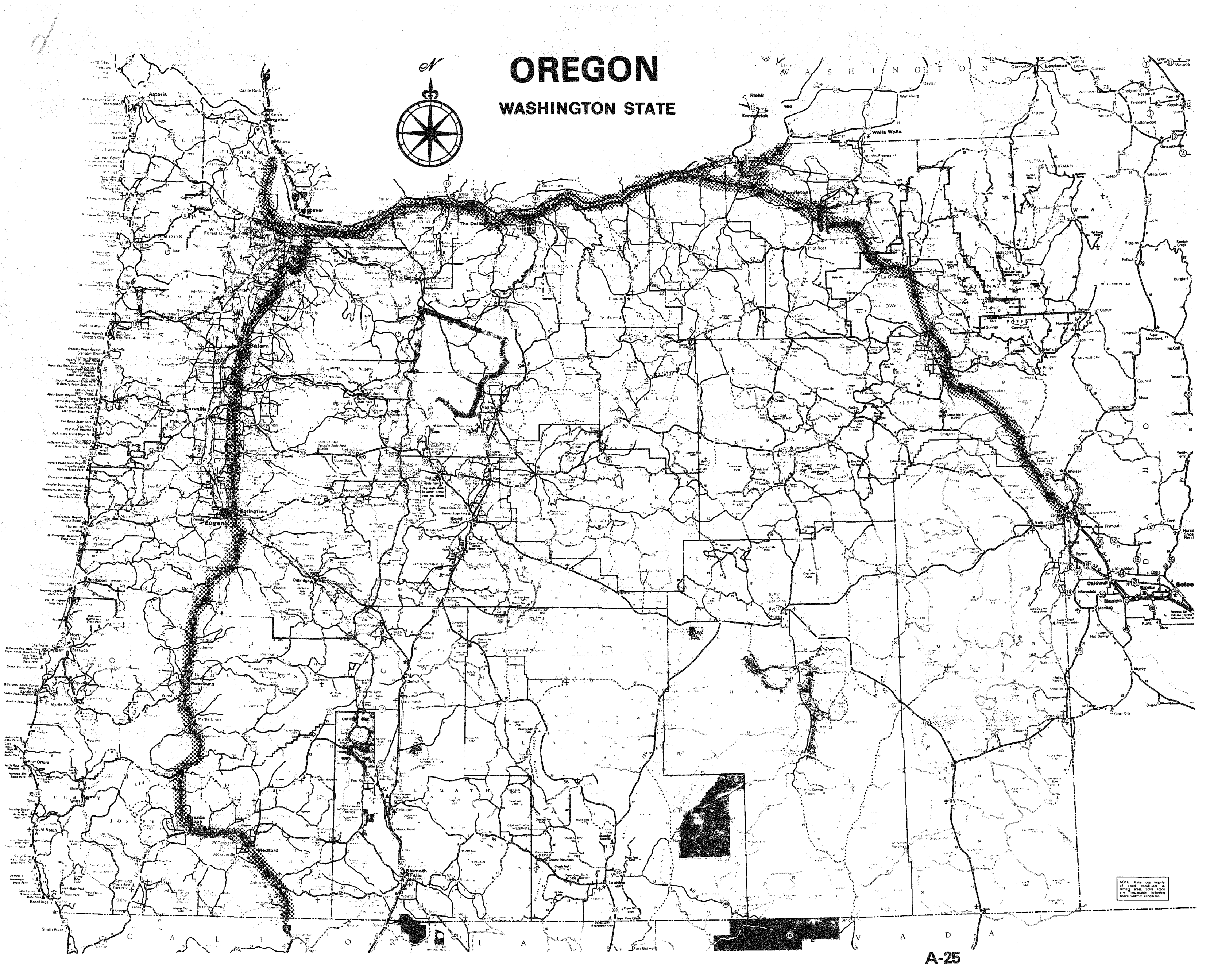




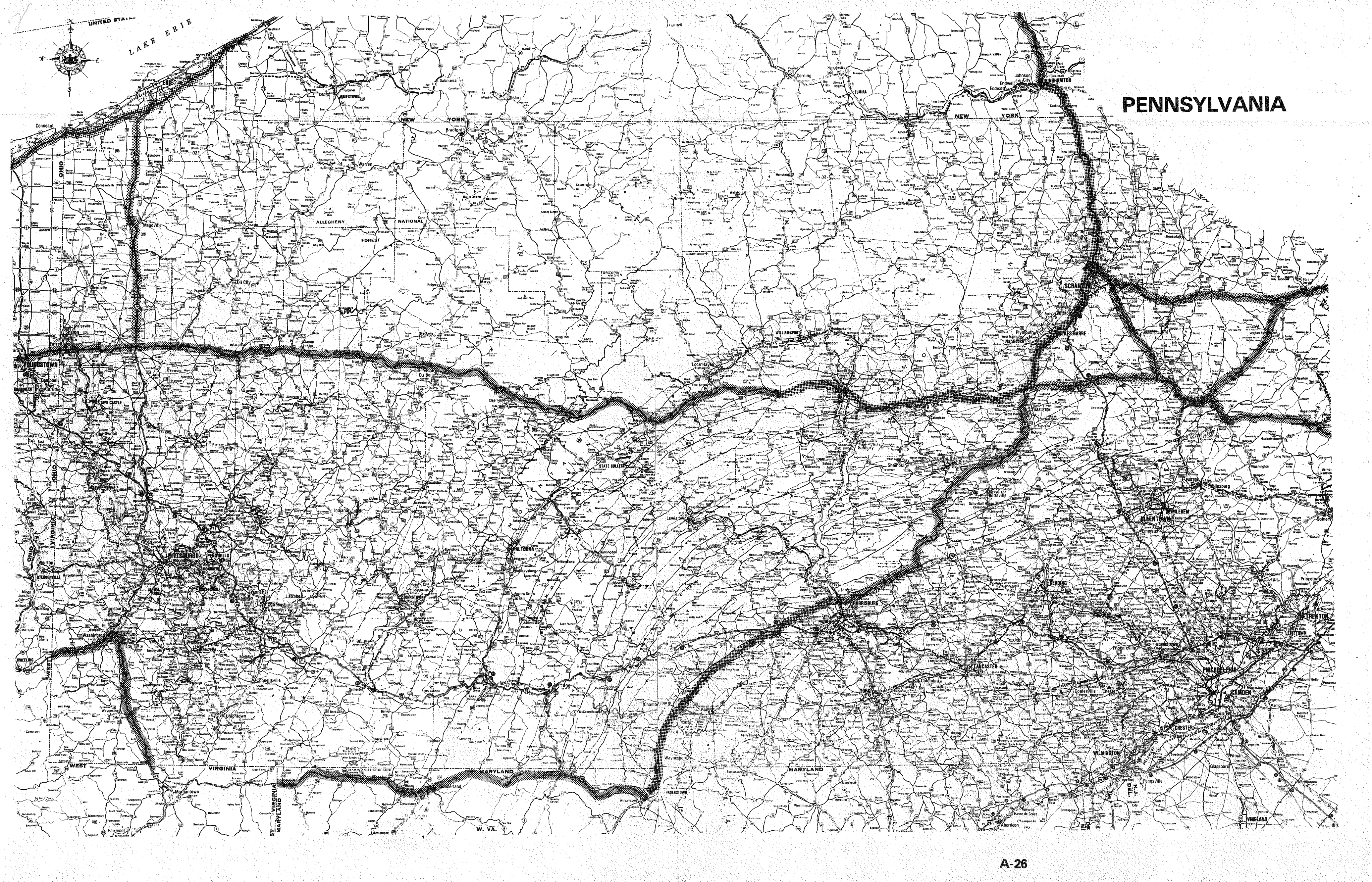




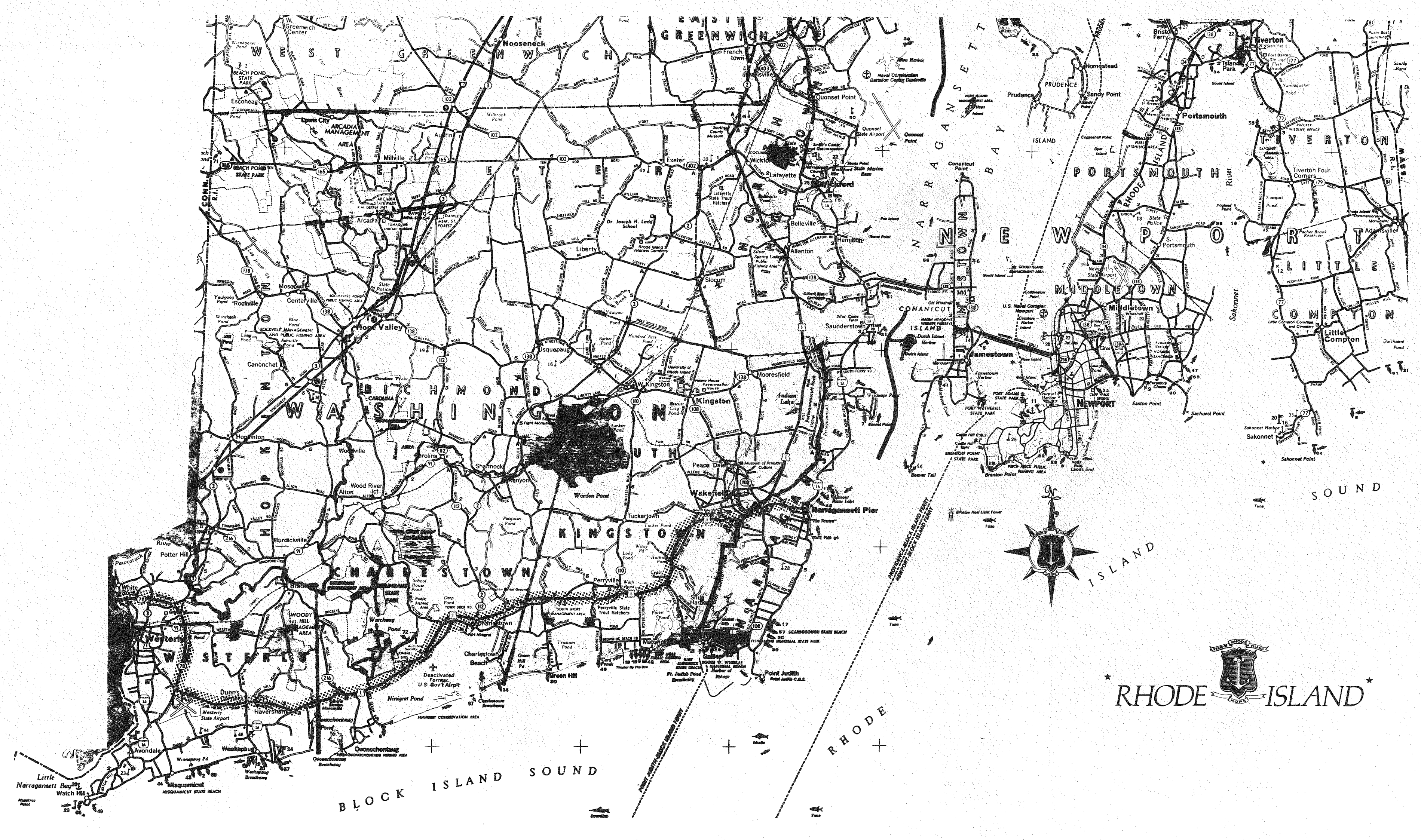




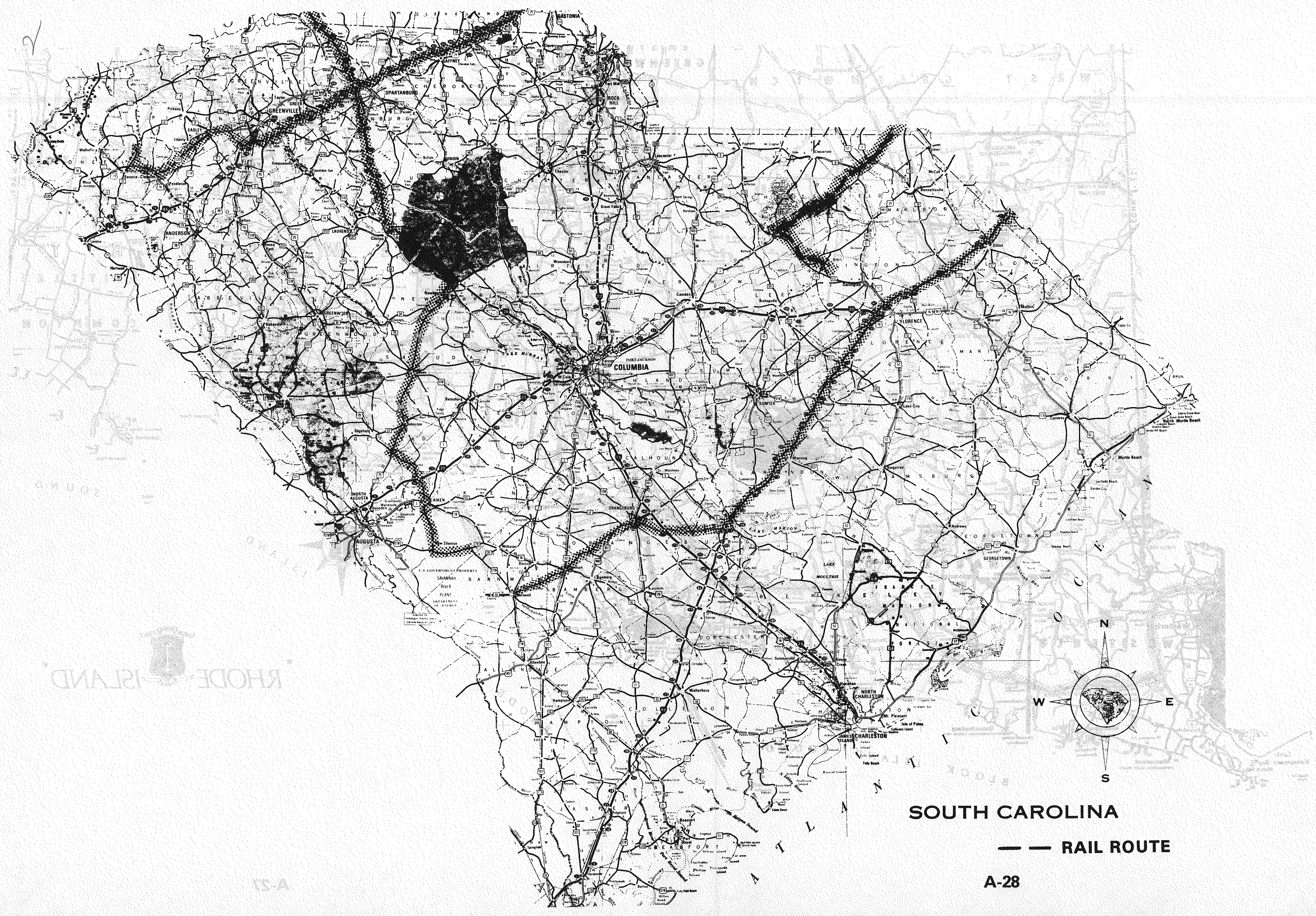




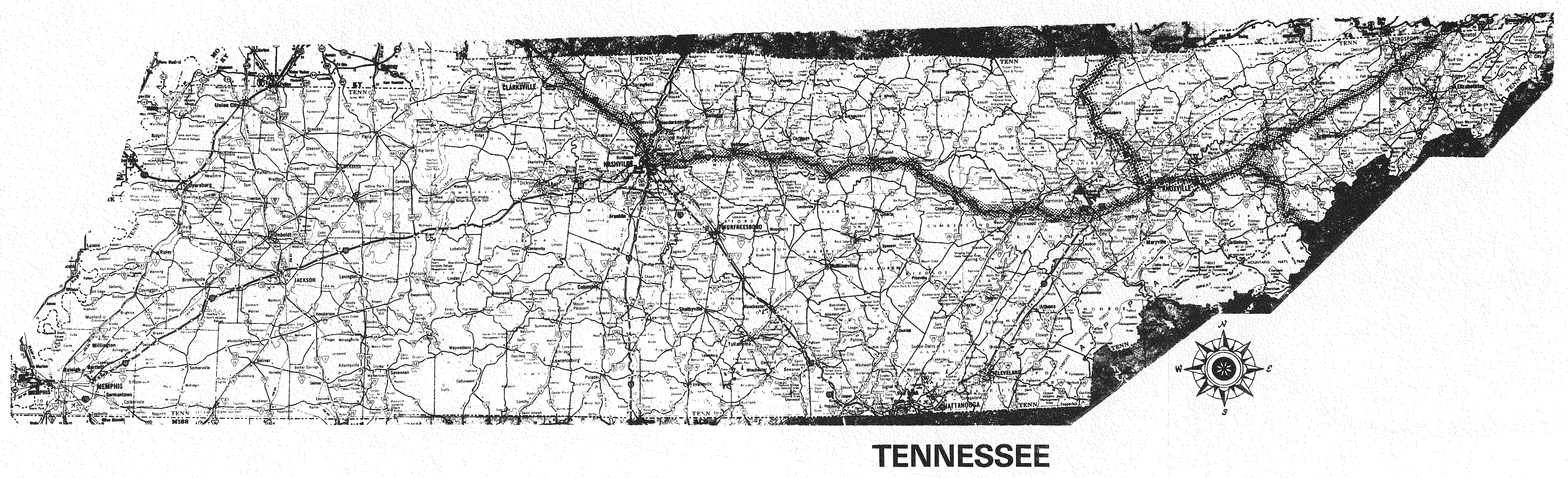



-

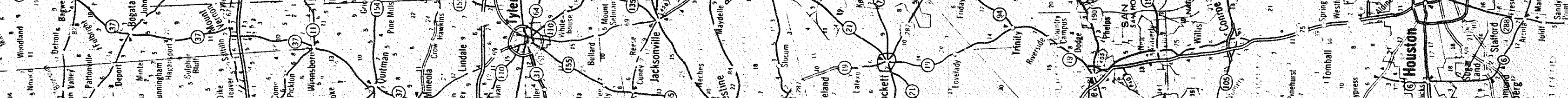
TH S. $-v_{1}$ $4^{2}$

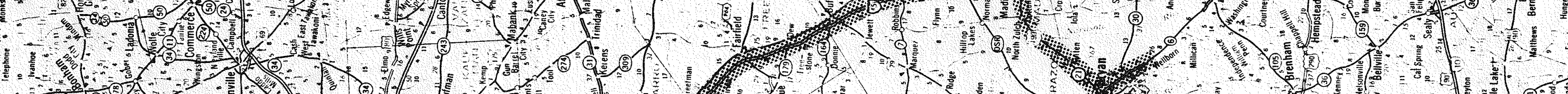

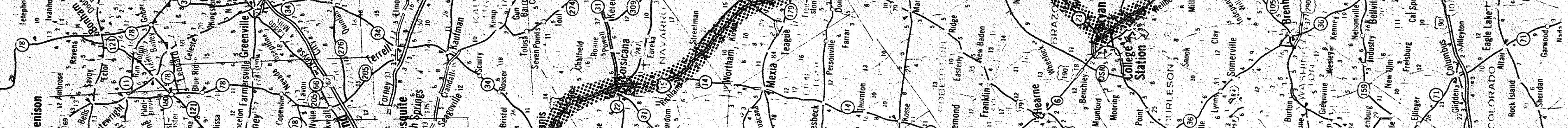

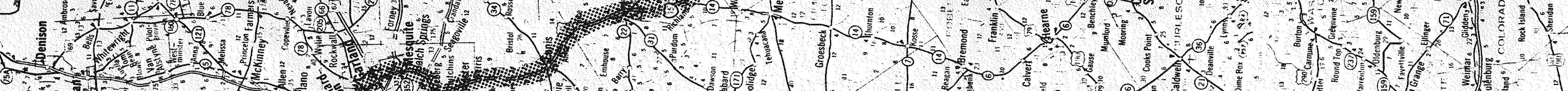

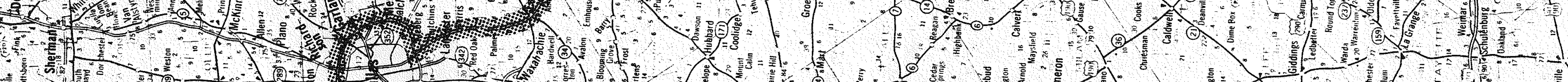

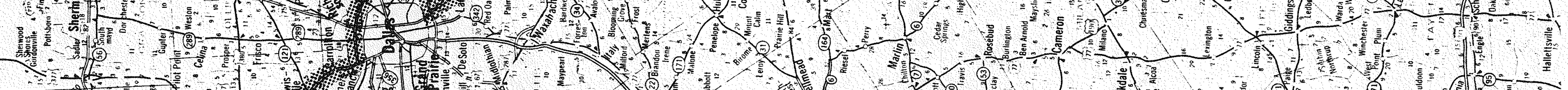
A

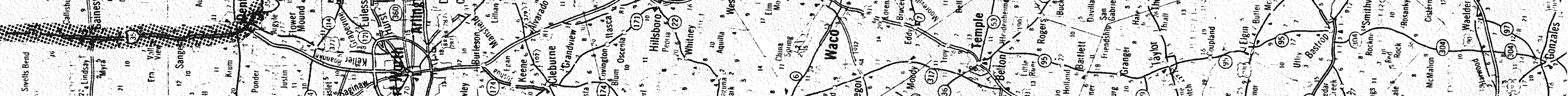

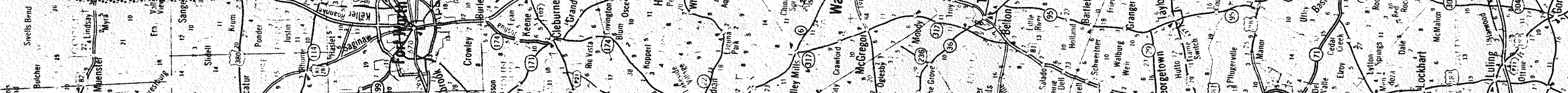

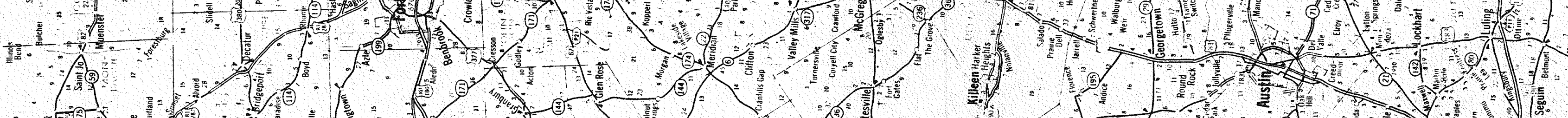

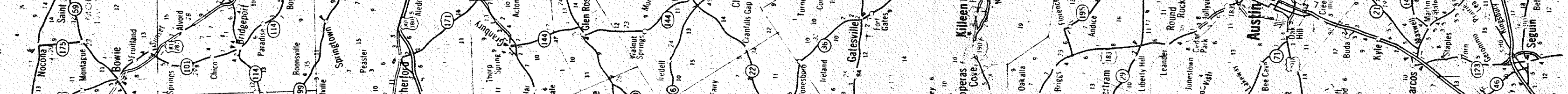

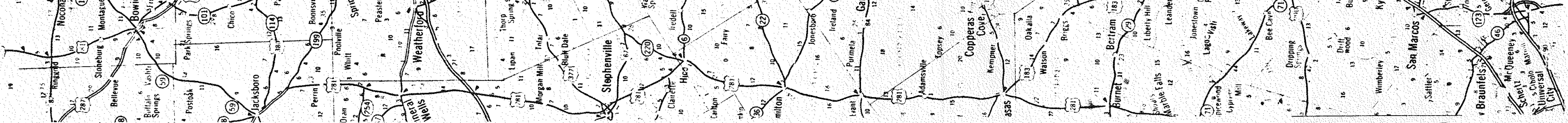




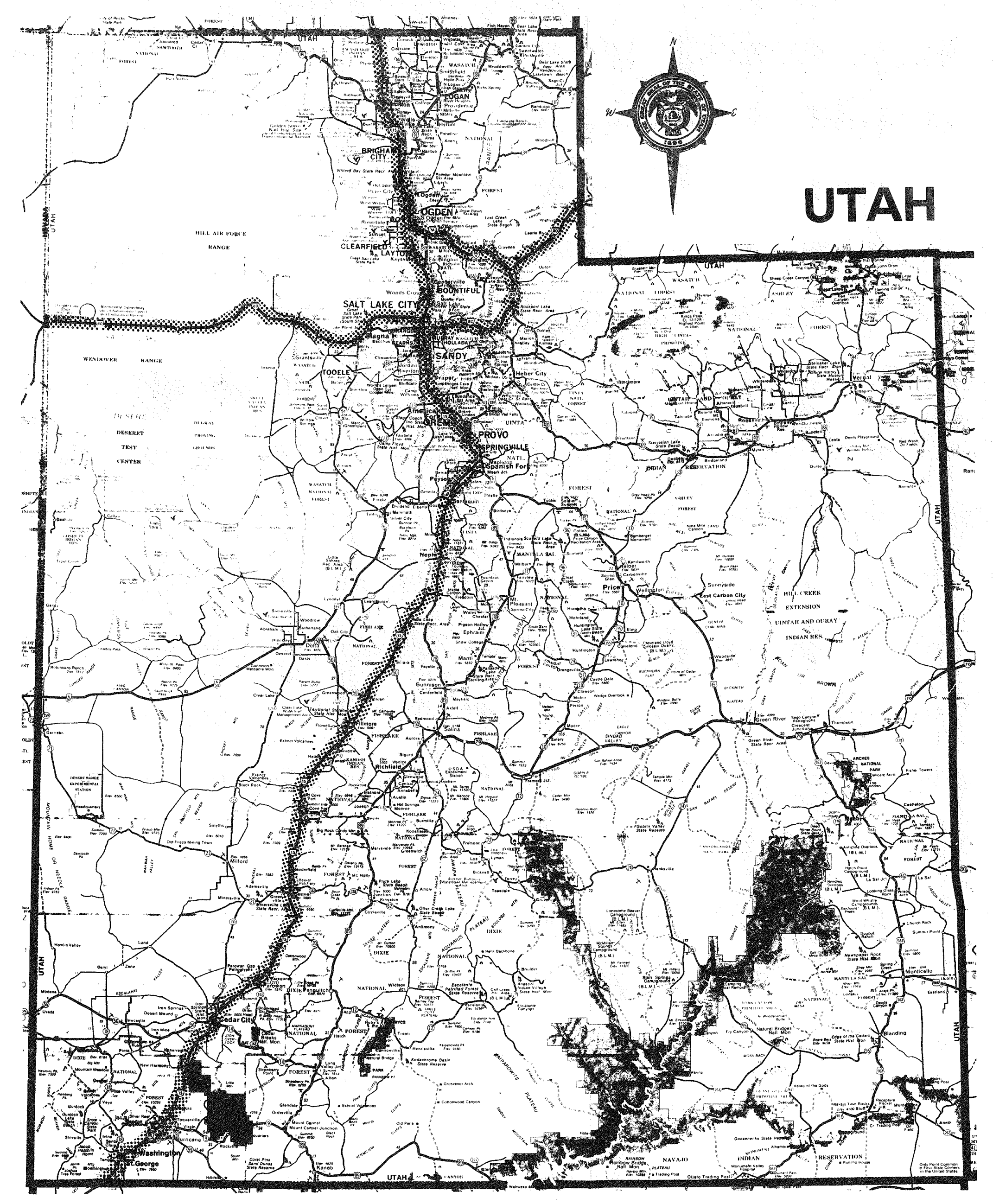

A-31 
(b)

(1)

(1)

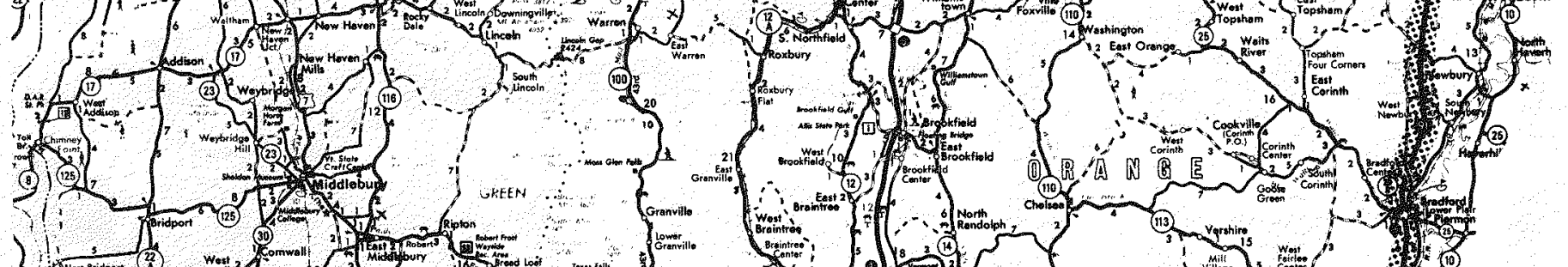

(1)

w

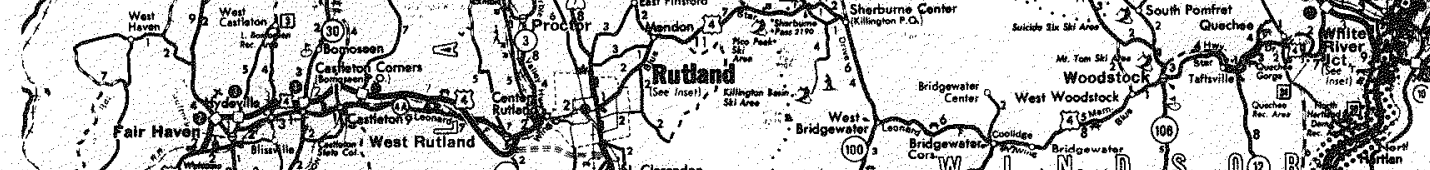

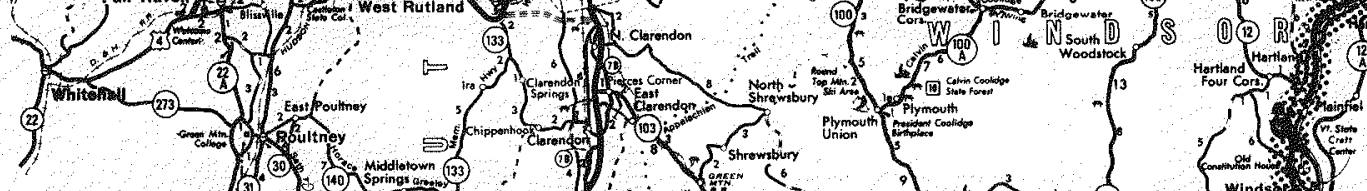

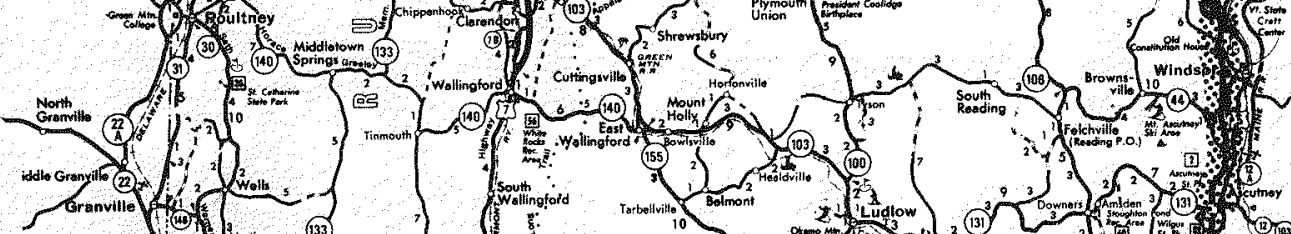

VERMONT

(1)

(and (3)

(n)

10

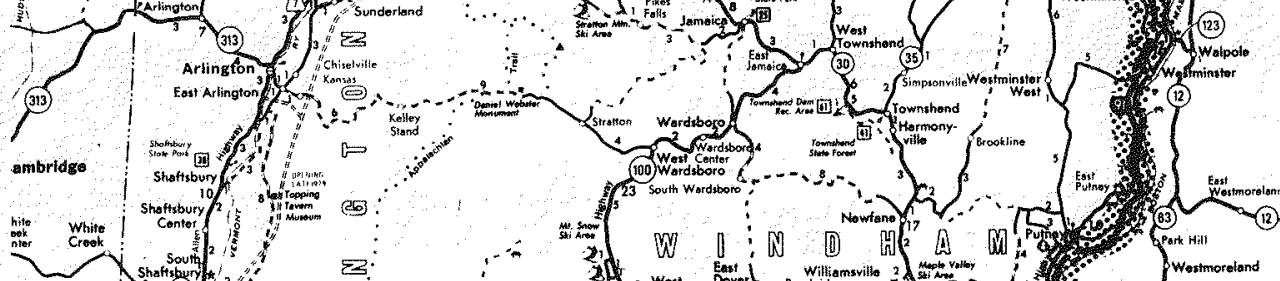

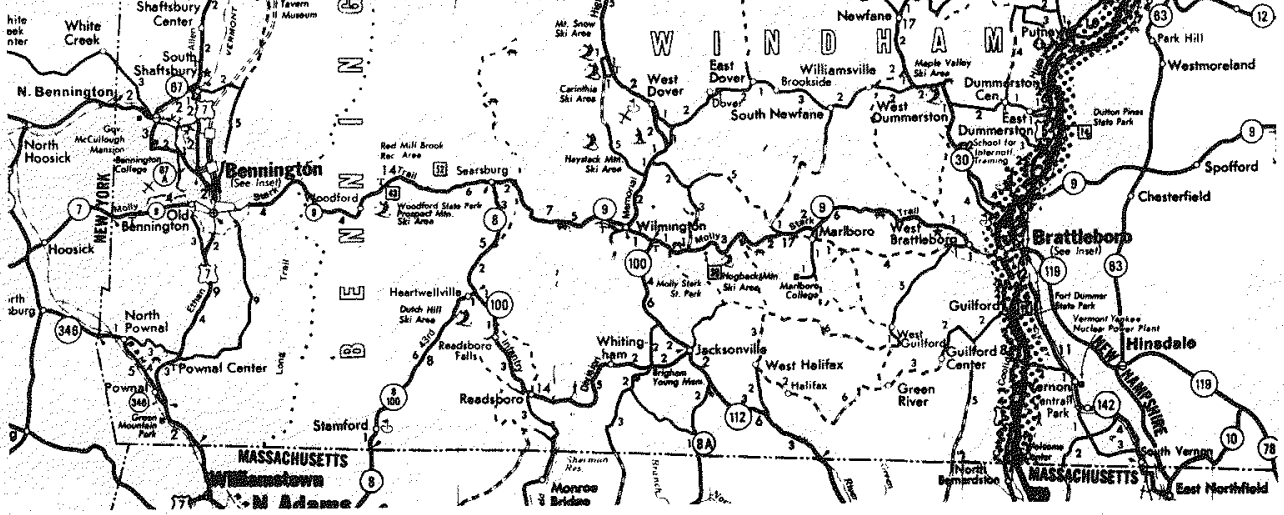




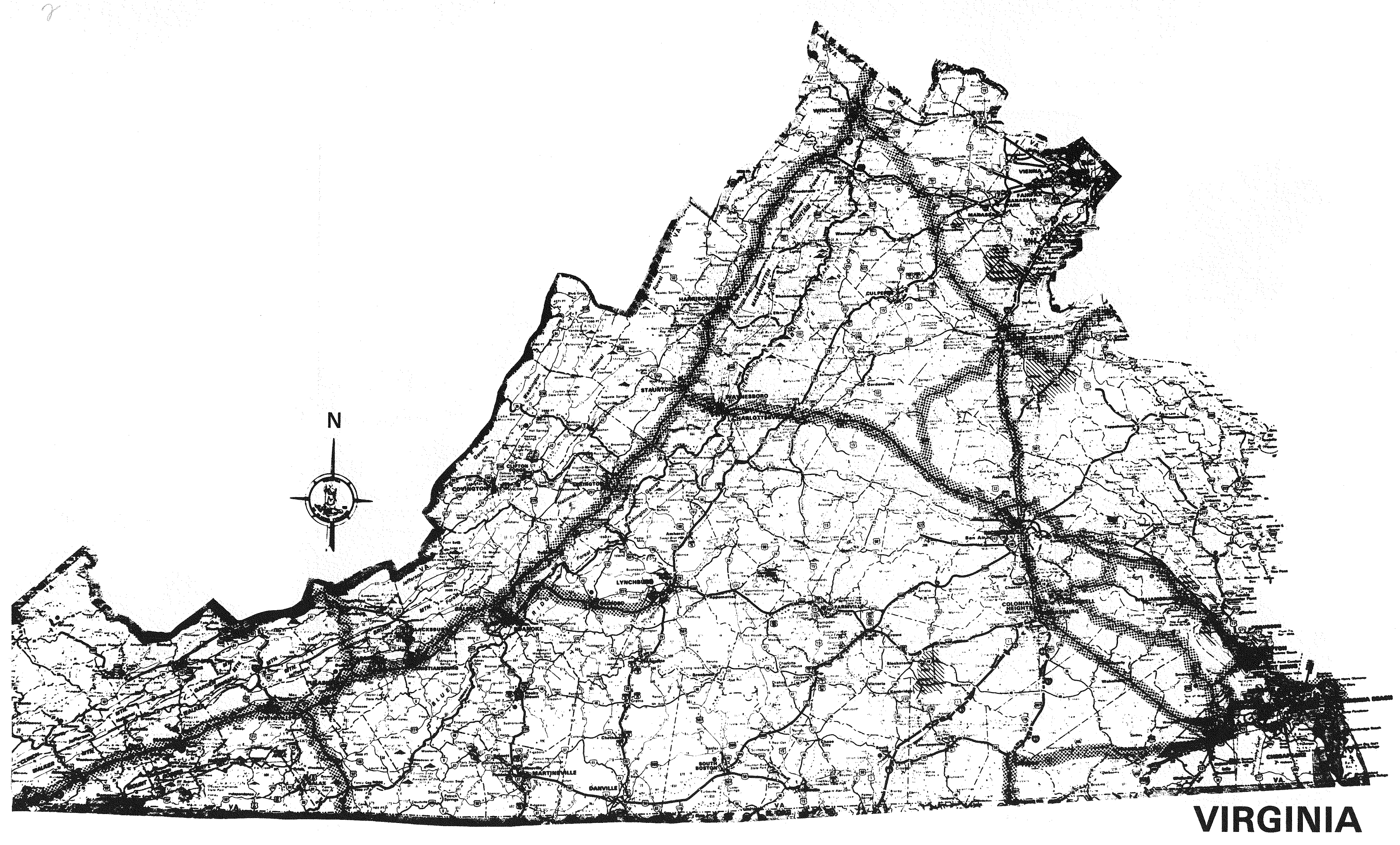




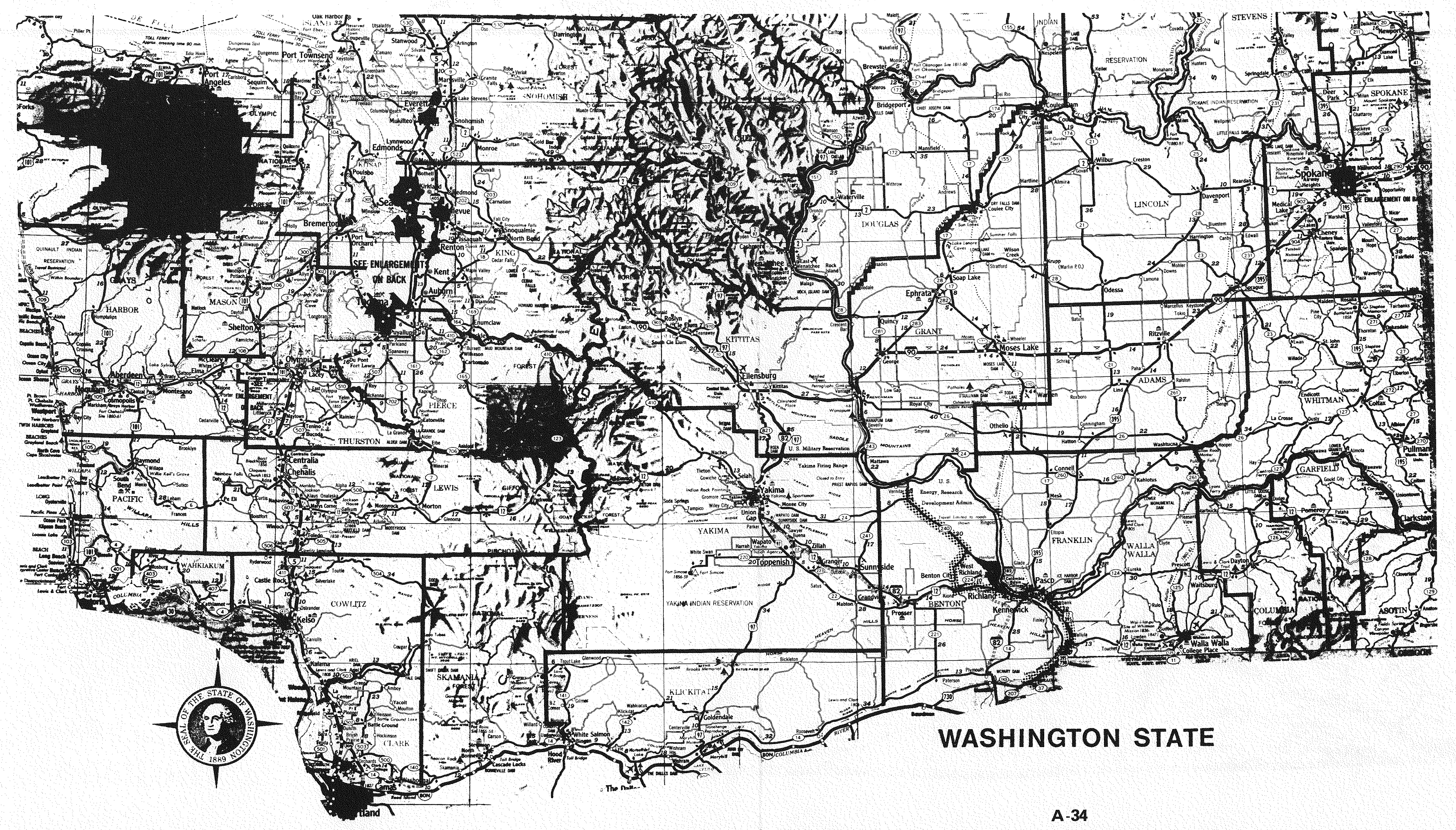




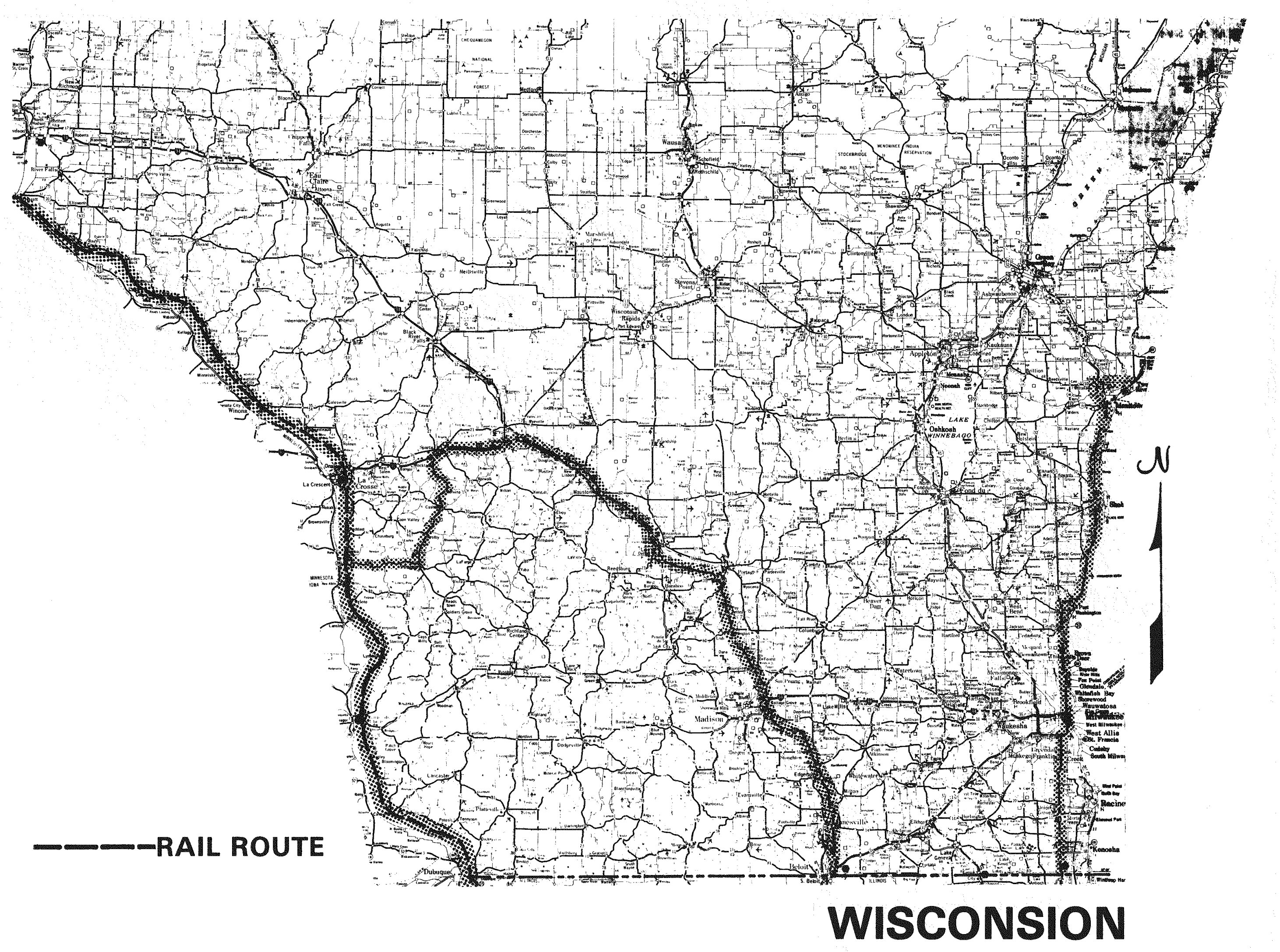




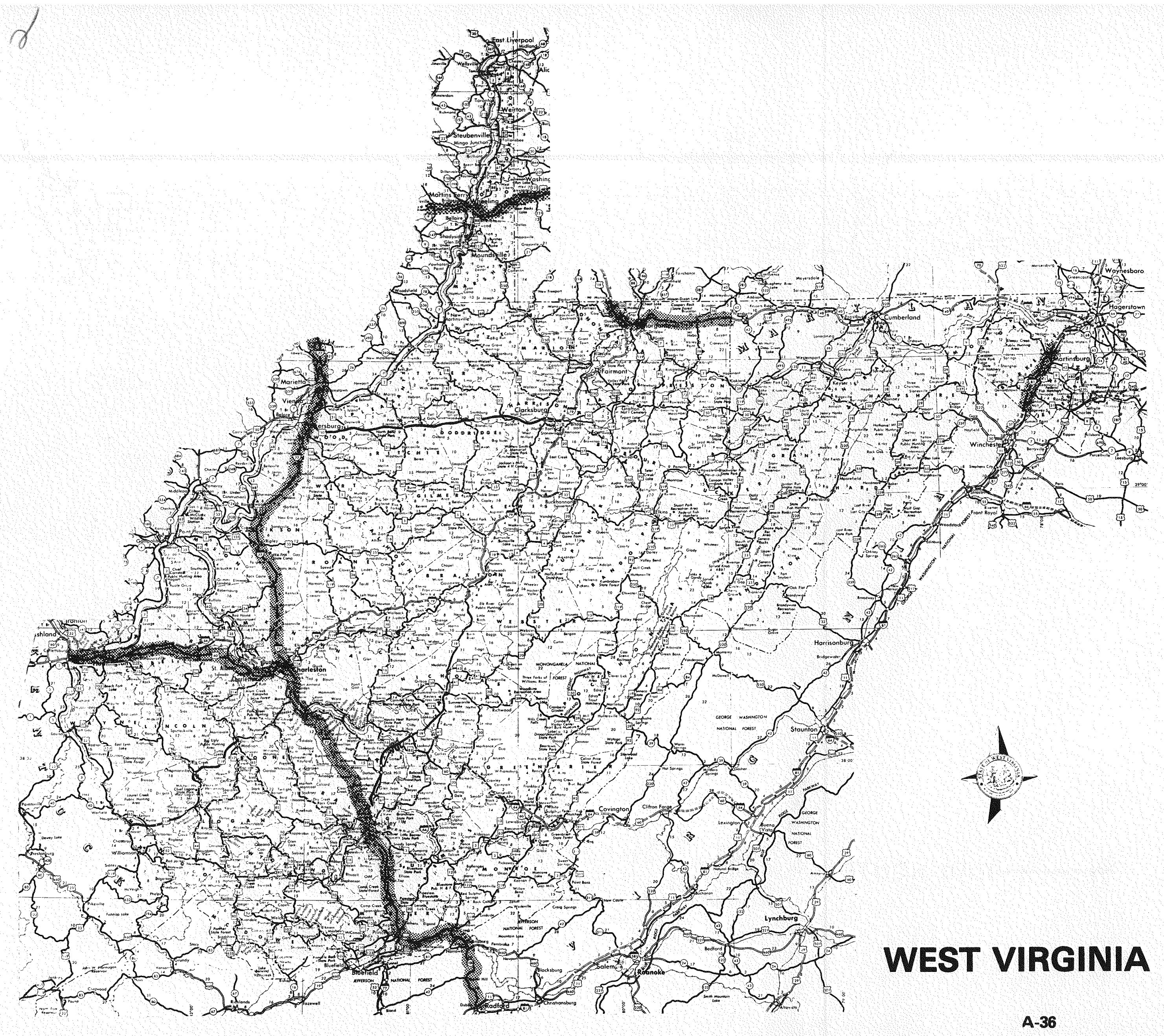




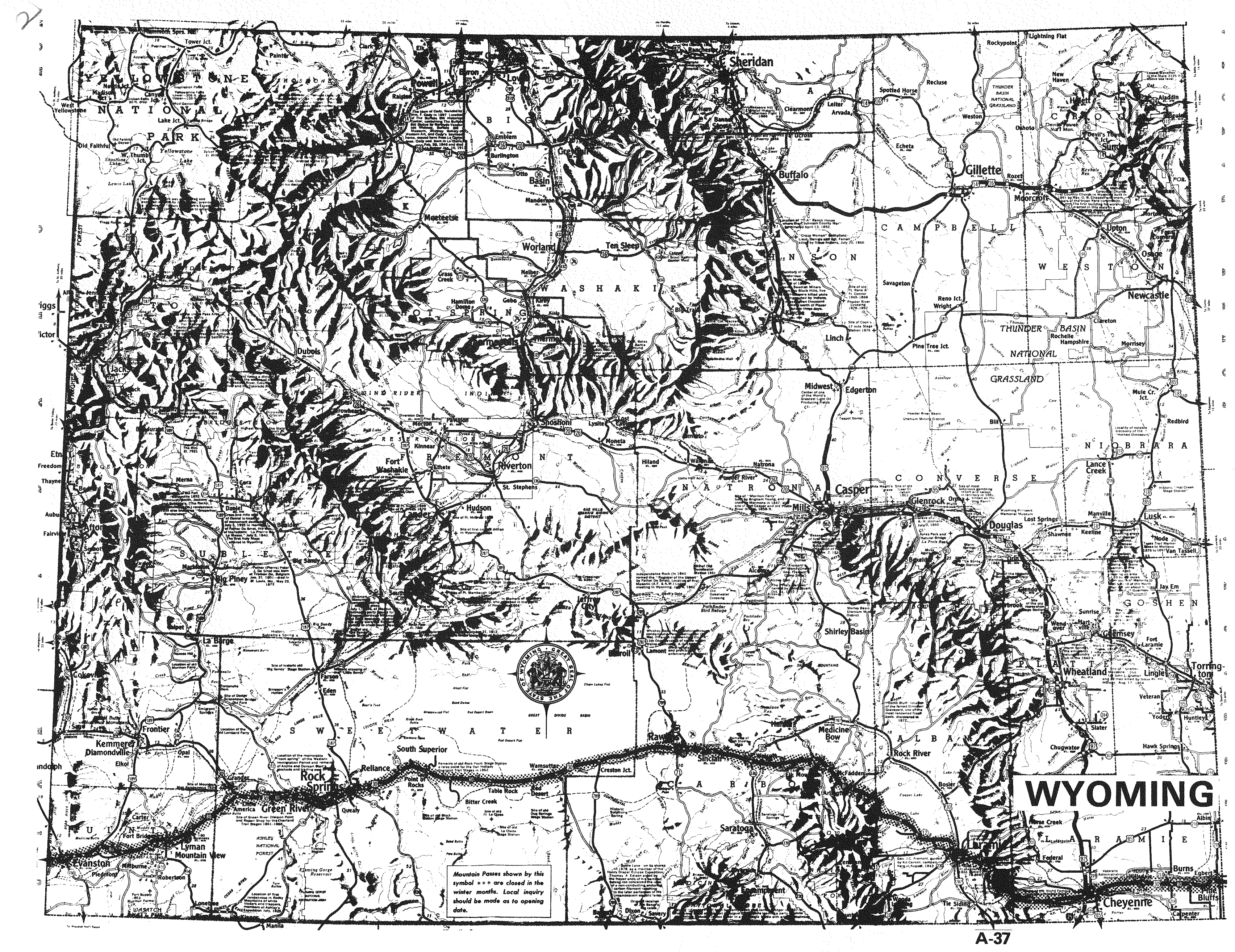

